\title{
Targeted Esterase induced Dye loading supports Calcium Imaging in Eukaryotic Cell-Free Systems
}

\author{
Priyavathi Dhandapani ${ }^{a}$, Srujan Kumar Dondapati ${ }^{a}$, Anne Zemella $^{a}$, Dennis Bräuer ${ }^{a}$, Doreen Anja Wüstenhagen ${ }^{a}$, \\ Stefan Kubick $^{\text {a, b }}$ \\ a) Fraunhofer Institute of Cell Therapy and Immunology, Branch Bioanalytics and Bioprocesses (IZI-BB), Am Mühlenberg 1, Potsdam-Golm. \\ b) Faculty of Health Sciences, joint Faculty of the Brandenburg University of Technology Cottbus - Senftenberg, the Brandenburg Medical School \\ Theodor Fontane and the University of Potsdam.
}

\begin{abstract}
Calcium imaging is an important functional tool for addressing ion channels, transporters and pumps for drug screening in living cells. Depicted eukaryotic cell-free systems utilize microsomes, derived from endoplasmic reticulum to incorporate the synthesized membrane proteins. Absence or inadequate amount of carboxylesterase in the endoplasmic reticulum of eukaryotic cells, which is necessary to cleave the acetoxymethyl ester moiety of the chemical calcium indicators, advocates the hindrance to perform calcium imaging in microsomes. In this work, we try to overcome this drawback and adapt the cell-based calcium imaging principle to a cell-free protein synthesis platform. Carboxylesterase synthesized in a Spodoptera frugiperda Sf21 lysate translation system is established as a viable calcium imaging tool and hTRPV1 is used as a model channel protein to demonstrate the realization of this concept.
\end{abstract}

\section{INTRODUCTION}

Calcium permeable membrane proteins such as ion channels, transporters and pumps, contribute to the majority of eukaryotic membrane proteins, serving as viable drug targets for several pathological diseases next to the large family of G-protein coupled receptors (1). Eukaryotic cell-free protein translation overcomes several disadvantages that could be met for overexpression of ion channels, transporters and pumps such as cell-toxicity, poor expression and deletion due to engineered protein domains (2). As eukaryotic cell-free translated membrane proteins are incorporated into microsomal membranes and removal of the plasma membrane during lysate preparation grants us with numerous advantages of working with plasma membrane channels in the microsomes. One big advantage is that increased signal to noise ratio in assays over cell-based expression. In cell-based protein expression, ion channels are evaluated using non-functional assays such as ligand binding assays and functional assays such as automated and manual electrophysiology as well as voltage and ion sensitive dye binding assays. Although many researchers have worked on ion channels synthesized using prokaryotic cell-free synthesis, little work on ion channel expression and functionality with eukaryotic systems have been done till date. Some of them are: planar bilayer measurements such as alpha7 nicotinic acetylcholine receptor $(\mathrm{nAChR})(3)$, connexion gap junction channels (4) in a rabbit reticulocyte lysate translation system, (human voltage dependent anionic channel (hVDAC1) (5), K channel of streptomyces A (KcSA) (6), Bombyx mori olfactory receptor BmOR1 (7) in a Spodoptera frugiperda $S f 21$ lysate translation system, shaker potassium channels (8) in the wheat germ cell extract translation system; membrane topogenesis studies in microsomes such as Inward-rectifier potassium channel (Kir 2.1) and KcsA (9) in the rabbit reticulocyte system. 
Although some current evidences have been reported for electrophysiological experiments, no evidence on functionality assays with ion and voltage sensitive dyes is currently available. The concept of calcium imaging of eukaryotic cell-free translated channels revolves around the previously reported idea of Targeted Esterase induced Dye loading (TED) of the endoplasmic reticulum (ER) in mammalian cells (10, 11). We use a mouse carboxylesterase 2 ( $m$ CES2) variant because, it is already well characterized for low affinity chemical fluorescent calcium dyes (10). We focus on studying calcium, being customarily a permeabilized ion through several families of ion channels and a second messenger in signal transduction in large number of cellular pathways. Intraluminal calcium is the prime regulator for ER function, which has also been studied concomitantly in microsomes by researchers in last decades. Using non-fluorescent methods such as radioactive labelling of calcium ions, extensive studies have been reported using rat brain microsomes $(12,13)$, hepatic microsomes $(14)$ and rabbit skeletal microsomes (15). All the aforementioned radioactive $\mathrm{Ca}^{2+}$ uptake and release studies have been performed only for native channels and pumps present in the ER such as Sarcoplasmic reticulum Calcium ATPase (SERCA) and leak channels such as Ryanodine receptors (RyR1 and RyR2).

\section{RESULTS AND DISCUSSION:}

\section{Cell-free synthesis using Sf21 system}

In order to establish a vesicle-based calcium imaging tool, mCES2 cell-free construct was used as depicted in Fig $1 \mathrm{c}$ to incorporate the soluble protein $m$ CES2 inside the lumen of microsomes during cellfree translation. A melittin signal sequence upstream of the gene was utilized as aforementioned (16). As the model protein $h$ TRPV 1 is a poly transmembrane channel, no signal sequence is necessary for active incorporation into microsomal membranes. A CrPV IRES site upstream of the gene for both $m$ CES 2 and hTRPV1 was used with a start codon as GCT, alanine instead of ATG, methionine for improved translation as reported before for other proteins (17). T7 promoter and T7 terminator was used for mRNA transcription. For cell-free synthesis of $m$ CES2 and $h$ TRPV1, we used the Continuous Exchange Cell-Free (CECF) mode of our Sf21 translation system $(18,19,20)$. This mode of synthesis has mainly the amino acids and the energy components in the larger compartment and the eukaryotic translation mix in a smaller compartment separated by a dialysis membrane of $9 \mathrm{kDa}$ cut off. Caspase inhibitor was used for improved yields and avoiding protein degradation during the incubation step of $24 \mathrm{~h}$. Though the total translation mix contained $85 \mathrm{ng} / \mu \mathrm{l}$ of the de novo synthesized mCES2 protein, only $25 \mathrm{ng} / \mu \mathrm{l}$ was obtained in the vesicular fraction. For expression of both the proteins, $h$ TRPV1 and $m$ CES 2 were correspondingly sequentially translated for $24 \mathrm{~h}$ each. As the microsomes obtained from the first translation were used in the second translation, it may occur that the first translated protein is not present in all the microsomes at the end of the second translation. To avoid this issue, we have used only the vesicular fraction obtained after second translation for all our experiments that require tandem protein translation. Simultaneous translation is not preferred as evaluating the amount of individual proteins synthesized is not feasible. $m$ CES2 and hTRPV1 synthesized showed a molecular weight of 58 $\mathrm{kDa}$ and $98 \mathrm{kDa}$ correspondingly under reduced conditions. As $m$ CES 2 and $h$ TRPV1 contain di-sulphide bridges, prudently the translation is synthesized only under non-reducing conditions. 


\section{Validation of synthesized $m$ CES2 in microsomal lumen}

Carboxylesterases are present in the cytosol in large quantities, which also results in the lysate. Apparently, the cytosolic carboxylesterase is likely to be present outside the microsome and will not contribute for any applications like calcium imaging of microsomes. Prior to functional assessment, intensive washing of microsomes was performed to remove the cytosolic esterase. Functionality of the $m$ CES2 synthesized inside the microsomes is assessed using the commonly used para-nitrophenyl acetate (PNPA) method $(21,22)$ (Fig 2). The PNPA method provides a faster way to assess the esterase activity. The esterase activity is preferably analysed for maximum $1 \mathrm{~h}$ in accordance with the time frame for calcium imaging applications. mCES2 microsomes showed higher esterase activity relative to NTC microsomes in a substrate dependent (Fig 2 b) plot, time dependent and dose dependent (Fig 2 d, supplementary data 1) measurements. The activity observed in the NTC microsomes is probably due to unspecific activity of hydroxylase or a mono-oxygenase class of cytochrome P450 enzymes present in the endoplasmic reticulum $(23,24)$.

For calcium experiments, Fluo-5N AM was used due to the low binding affinity $(90 \mu \mathrm{M})$ for $\mathrm{Ca}^{2+}$. The masked negative charge of the dye by acetoxymethyl ester moiety is unveiled with the aid of $m$ CES2 inside the microsomes as shown in the schematic depiction Fig 3 a. For all experiments in the acetoxymethyl ester cleavage studies in Fig 3 b, c and d, no dye loading enhancers like pluronic F-127, probenecid or saponin were used due to their interference in fluorescence measurement caused by additive loading $(25,26)$. Both time dependent plot and substrate dependent plot showed a higher amount of dye loaded and cleaved for AM moiety. $5 \mu \mathrm{M}$ of Fluo-5N AM was used for dye loading experiments measured by a microplate reader, $2 \mu \mathrm{M}$ of Fluo-5N AM was enough for qualitative and quantitative measurements of calcium with confocal microscopy without any loading enhancers from $S f 21$ cell-free lysate. The $m$ CES2 overexpression inside the microsomes significantly enhances the amount of dye loaded and reduces dye incubation time. As the Sf21 microsomes from the cell-free lysate undergo the translation reaction for $24 \mathrm{~h}$ at $30{ }^{\circ} \mathrm{C}$, the esterase activity from the NTC microsomes is expected to be lower than the microsomes that are prepared for other purposes. Nevertheless, overexpression of $m$ CES2 cuts down the concentration of Fluo-5N AM required for qualitative calcium measurements.

\section{Establishment of TED based calcium imaging in microsomes}

The $K_{d}$ of Fluo-5N AM for $S f 21$ lysate microsomes was calculated to be $265 \mu \mathrm{M}$ (Fig 4 a). The experiment was performed by first chelating resting calcium levels in the microsomes by 5 mM EGTA and then sequentially increasing the concentration of $\mathrm{Ca}^{2+}$ from 0 to $1 \mathrm{mM}$ every step by $100 \mathrm{nM}$ in the presence of $10 \mu \mathrm{M}$ ionomycin. The $K_{d}$ in phosphate buffer saline reported was $90 \mu \mathrm{M}$ (27). The $K_{d}$ in vitro or in vivo is usually higher than in the buffer which varies among different biological systems and experimental conditions. Sarcoplasmic reticulum vesicles for example from rabbit ventricular myoctes show a $\mathrm{K}_{d}$ of 400 $\mu \mathrm{M}(28)$ and mouse skeletal muscle sarcoplasmic reticulum have $K_{d}$ of $133 \mu \mathrm{M}$ (29). The $K_{d}$ in vitro or in vivo is usually higher than in the buffer due to the varied expression of calcium binding proteins. In case of microsomes, it is due to the presence of calcium binding proteins derived from the sarcoplasmic reticulum like soluble calreticulin and single pass membrane protein calnexin that compete with Fluo-5N AM for luminal calcium (30). 
Studying the ER resident proteins, using AM calcium dyes in the mCES2-expressive microsomes has several advantages over the endoplasmic reticulum in cell-based assays. As the low affinity AM dyes have to reach the endoplasmic reticulum through the cytosol where the carboxylesterases are abundant, a significant amount of fluorescent dye is cleaved and remain in the cytosol. Despite using low affinity $\mathrm{Ca}^{2+}$ indicators, which diminish the sensitivity to cytosolic $\mathrm{Ca}^{2+}$ levels, it will still contribute to the large noise relative to signal due to the high amount of cleaved dye present in the cytosol. Another advantage is that, it gives the flexibility to alter the calcium levels outside the microsomes, which could not be done likewise with cytosolic calcium levels. Largely, it aids in reducing the intrinsic calcium leakage due to the potentiation of $\mathrm{Ca}^{2+}$ between the luminal and outer face of the microsomes. It has already been proposed that by reducing the ER/SR calcium levels, one can reduce the calcium leakage of the SR in cells. In the case of ER derived microsomes, this is not necessary as we could increase the extramicrosomal $\mathrm{Ca}^{2+}$ to reduce the potentiation (31). For all calcium experiments, we used $200 \mu \mathrm{M}$ calcium in the buffer in order to reduce the leakage from microsomes. Using $300 \mathrm{nM} \mathrm{Ca}^{2+}$ in the buffer caused extensive leakage relative to the $200 \mu \mathrm{M} \mathrm{Ca}^{2+}$ buffer as shown in supplementary data 2.

In order to study the native proteins in microsomes, extensively investigated proteins such as sarcoplasmic reticulum ATPase (SERCA) and ryanodine receptors were choice of interest. In Sf21 microsomes, SERCA activity was previously recorded with radiolabelled ${ }^{45} \mathrm{Ca}^{2+}(32,33)$. SERCA activity at room temperature was observed for about $30 \mathrm{~min}$ in the presence of $10 \mathrm{mM}$ ATP with a slow increase in microsomal $\mathrm{Ca}^{2+}$ (Fig 4 b). Change in temperature alters the $\mathrm{K}_{d}$ with change in the sensitivity range and the fluorescence life time which in turn affects the bleaching rate of the Fluo-5N AM (34). As expected, we also observed that the $\mathrm{K}_{d}$ is lower and high bleaching was observed at $37^{\circ} \mathrm{C}$ compared to room temperature (data not shown). Hence, to avoid artifacts caused by temperature, we preferred to evaluate the increase in $\mathrm{Ca}^{2+}$ levels in microsomes at room temperature after treatment of microsomes at $37^{\circ} \mathrm{C}$ with ATP. SERCA activity cannot be monitored alone as $\mathrm{Mg}^{2+}$ ATPase also comes into play in the presence of ATP (35). Moreover, $\mathrm{Mg}^{2+}$ is necessary for SERCA activity and Fluo-5N AM binds to $\mathrm{Mg}^{2+}$ up to a certain extent with lower affinity relative to $\mathrm{Ca}^{2+}$ (Thermofisher Catalogue), it is to be observed that, SERCA activity measurement both indirectly by inorganic phosphate and directly by fluorescent indicators include $\mathrm{Mg}^{2+}$ ATPase activity as well. Microsomal preparations in general, include EDTA that can chelate both $\mathrm{Ca}^{2+}$ and $\mathrm{Mg}^{2+}$. Moreover, the cell-free lysate preparation procedure includes especially EGTA, a $\mathrm{Ca}^{2+}$ specific chelator for arresting the $\mathrm{S7}$ nuclease treatment in the course of the process. On other hand, the calcium levels inside the microsomes could also be loaded up during the cell-free protein synthesis, as this reaction is performed with $\mathrm{Mg}^{2+}$ and $1 \mathrm{mM}$ ATP at $30^{\circ} \mathrm{C}$ for $24 \mathrm{~h}$. The typical $\left[\mathrm{Ca}^{2+}\right.$ ] concentrations in the ER varies from few $\mu \mathrm{M}$ to $\mathrm{mM}$ (36). Calcium binding proteins like calreticulin, calnexin, GRP78 (BiP), GRP94, ERp72, protein disulfide isomerase, reticulocalbin, and ERC55 act as buffer causing the multiple order of variation in the $\left[\mathrm{Ca}^{2+}\right]$ of the ER due to different individual binding affinities $(36,37)$. The binding affinity for the $\mathrm{Ca}^{2+}$ buffering proteins are reported to be in the range of $\mathrm{mM}(38)$. In order to estimate the amount of calcium present in the microsomes, we have used used $10 \mu \mathrm{M}$ ionomycin $+5 \mathrm{mM}$ EGTA for $\mathrm{F}_{\max }, 10 \mu \mathrm{M}$ ionomycin $+10 \mathrm{mM} \mathrm{Ca}^{2+}$ for $\mathrm{F}_{\min }$ using the formula,

$$
\left[\mathrm{Ca}^{2+}\right]=\mathrm{K}_{\mathrm{d}} *\left(\mathrm{~F}-\mathrm{F}_{\min }\right) /\left(\mathrm{F}_{\max }-\mathrm{F}\right)
$$

The representative graph for calcium concentration determination is shown in Fig $4 \mathrm{c}$ and $\mathrm{f}$. The sensitivity of the Fluo- 5N AM that can be visually observed is shown in Fig 4 e, representing I, II, III experimental conditions. With depletion of $\mathrm{Ca}^{2+}$ in microsomes, the decrease in fluorescence is noted in 
II and when the buffer is completely exchanged to $10 \mu \mathrm{M} \mathrm{Ca}^{2+}$, the increase in intensity is observed in III as recorded in video of Supplementary data 3. The estimated $\left[\mathrm{Ca}^{2+}\right]$ in $S f 21$ microsomes that undergo CECF translation was estimated to be in the range of 100 to $1000 \mu \mathrm{M}$ (Fig 3) which is coherent with previously reported data in other eukaryotic cells. Microsomes treated with $10 \mathrm{mM} \mathrm{ATP}, 1 \mathrm{mM} \mathrm{Mg}^{2+}$ with $200 \mu \mathrm{M} \mathrm{Ca}{ }^{2+}$ for $1 \mathrm{~h}$ at $37^{\circ} \mathrm{C}$, showed a 4-5 times higher range of luminal $\mathrm{Ca}^{2+}$. The in-vitro $\mathrm{K}_{\mathrm{d}}$ which we estimated is $265 \mu \mathrm{M}$, and it is approximately $3 \mathrm{X}$ higher compared to the $\mathrm{K}_{\mathrm{d}}$ in the buffer solution. The sensitivity range or dynamic range of Fluo- $5 \mathrm{~N}$ vary from $10^{-7}$ to $10^{2} \mathrm{M}$ of $\mathrm{Ca}^{2+}$ in vitro for the sarcoplasmic reticulum (29). Microsomes treated for SERCA activity showed a median value of $2500 \mu \mathrm{M}$ which is in accordance with the expected sensitivity range (Fig $4 \mathrm{c}$ ).

Ryanodine receptors, RYR1 and RyR2 perform a plethora of functions in mammalian physiology ranging from skeletal muscle and cardiac muscle contraction, cognitive functions such as learning and memory. Ryanodine channels that deplete the calcium stores in response to ryanodine are ER resident leak channels, RyRs respond to ryanodine at low concentration and caffeine. Ryanodine receptors have been extensively investigated in eukaryotic cells $(39,40,41,42)$. Fig $4 \mathrm{~d}$ represents the calcium response of $100 \mu \mathrm{M}$ and $10 \mathrm{mM}$ caffeine. $10 \mathrm{mM}$ caffeine induced a higher calcium efflux relative to $100 \mu \mathrm{M}$ caffeine.

\section{Analysis of cell-free synthesized $h$ TRPV1 channel}

In pursuance of calcium imaging with cell-free synthesized channels, we have chosen the human Transient Receptor Potential Channel, Vallinoid Receptor member 1 ( $h$ TRPV1) as a model protein. hTRPV1 expressed in cells in the plasma membrane has been studied for calcium entry into cytoplasm using fura 2-AM $(43,44)$.

hTRPV1 is largely present in the plasma membrane with the large $\mathrm{N}$ terminal and the $\mathrm{C}$ terminal stretches towards the cytosol in cells. As expected, in cell-free synthesis, the orientation of the protein incorporated in the microsome is opposite to that of the native plasma membrane orientation. Despite most of the activators and inhibitors for the TRP channel family are organic membrane permeable compounds, attention should be paid while working with the non-polar activators or inhibitors. All experiments depicted in Fig 5 are performed after calcium loading into the microsomes for $1 \mathrm{~h}$ in order to ensure higher $\left[\mathrm{Ca}^{2+}\right]$ inside the microsomes. With the above-mentioned experimental conditions, we have observed that the activation of the $h$ TRPV1 caused $\mathrm{Ca}^{2+}$ release from $h$ TRPV1- $m$ CES2 microsomes. Saturation of capsaicin induced $\mathrm{Ca}^{2+}$ release was observed even with $200 \mathrm{nM}$ of CAP in the $h$ TRPV1$m$ CES2 microsomes. The $\mathrm{Ca}^{2+}$ release by $200 \mathrm{nM}$ CAP was abolished completely $20 \mu \mathrm{M}$ capsazepine (CPZ) (Fig $5 \mathrm{c}$ ). The concentration for activation and inhibition of $h$ TRPV1 in our experiments are coherent with the molar range as the cell-based expression (45). Presence of Phosphatidylinositol 4,5-bisphosphate, $(4,5) \mathrm{PIP}_{2}$ for activation of TRP channels has been debated by several researchers $(46,47,48)$. In our work, we have shown that without external $(4,5) \mathrm{PIP}_{2}$, activation of TRPV1 was feasible. On the other hand, the phenomenon we observe can be supported by the presence of $(4,5) \mathrm{PIP}_{2}$ in the endoplasmic reticulum and in the cytosol $(48,49,50)$.

\section{CONCLUSION AND OUTLOOKS:}

Apart from the TED method, which we utilize in our work, also other fluorescent methods can be employed. For instance, using membrane impermeable $\mathrm{Ca}^{2+}$ dyes to measure the extramicrosomal solution, which works conversely to the TED -based method (51). But with this 
method, only absolute luminal calcium levels cannot be monitored. Only the fluctuation caused by calcium influx/efflux can be measured. Radioactive calcium measurements have widely been used by researchers for studying microsomes (13, 14, 15, 16). Major drawback when studying microsomes with ${ }^{45} \mathrm{Ca}^{2+}$ is that, first the microsomes should be loaded with ${ }^{45} \mathrm{Ca}^{2+}$ using SERCA for efflux studies. Without ${ }^{45} \mathrm{Ca}^{2+}$, only influx studies can be performed. In the above-mentioned methods, as extra microsomal calcium is monitored and the microsomes are not immobilised on the microplate/cuvette, live monitoring of $\mathrm{Ca}^{2+}$ is impracticable while exchanging activator and inhibitor solutions. Moreover, endpoint-based methods increase the material costs while studying the kinetics. As chemical calcium dyes are toxic upon prolonged usage in live cells or animal models, genetically encoded calcium indicators for ER, mitochondria and other organelles are new emerging areas of research since the development of genetically engineered D1ER from Roger.Y. Tsien group (52). Though, genetically encoded calcium dyes could be another alternative other than the TED based system, the practicability of D1ER expressed cell line for CFPS preparation should be tested. Membrane bound ER proteins are well retainable in microsomes. However, loss of lumen soluble proteins is expected on due course of cell-free lysate preparation.

Apart from calcium imaging in a CFPS platform using a chemical fluorescent dyes, there are other biological applications for carboxylesterases. Carboxylesterase have known to impart pesticide resistance in insects $(53,54)$. Carboxylesterases play an important role in xenobiotic metabolism of environmental toxins and drugs. Moreover, several human drugs are consumed as pro-drugs which are further processed in liver by carboxylesterases into active drug formulation $(55,56)$. In this work, we have shown that the functionally active carboxylesterases could be synthesized using CFPS platform. As the synthesized carboxylesterase is present in microsomal lumen, active transport of prodrugs across the microsomal membrane can also be monitored. Hence, in order to cope up with the sustenance needs of above-mentioned areas of carboxylesterase research, cell-free synthesized carboxylesterases could be a conducive platform thereby surpassing the conventional disadvantages of cell-based protein synthesis.

\section{MATERIALS AND METHODS:}

\section{Continuous Exchange Cell-Free (CECF) translation:}

Eukaryotic CECF translation of proteins were performed using $S f 21$ lysates in the special dialysis chamber containing two compartments separated by $10 \mathrm{kDa}$ cut off dialysis membrane in between reaction mixture and the feeding mixture. A $50 \mu \mathrm{L}$ standard reaction mixture of a $S f 21$ cell-free synthesis reaction in the reaction chamber was composed of $40 \%$ lysate, $30 \mathrm{mM} \mathrm{HEPES}-\mathrm{KOH}, 2.5 \mathrm{mM} \mathrm{Mg}(\mathrm{OAc})_{2}, 75 \mathrm{mM}$ KOAc , $0.25 \mathrm{mM}$ spermidine, $100 \mu \mathrm{M}$ of each canonical amino acid, nucleoside triphosphates $(1.75 \mathrm{mM}$ ATP, $0.30 \mathrm{mM}$ CTP, $0.30 \mathrm{mM} \mathrm{GTP}$, and $0.30 \mathrm{mM}$ UTP), $120 \mathrm{ng} / \mathrm{\mu l}$ plasmid DNA, and $1 \mathrm{U} / \mathrm{ml}$ T7 RNApolymerase, $20 \mu \mathrm{M}$ of PolyG, $30 \mu \mathrm{M}$ of the caspase inhibitor -Z-VAD-FMK (benzyloxycarbonyl-Val-AlaAsp(OMe)-fluoromethylketone), and $0.02 \%$ of sodium azide. The feeding mixture of $1 \mathrm{ml}$ contained all the above components except plasmid, PolyG, T7 RNA polymerase and $S f 21$ lysate. ${ }^{14} \mathrm{C}$-labeled leucine (100 dpm/pmol) for the detection of de novo synthesized proteins. For functional analysis, the proteins were synthesized in the absence of ${ }^{14} \mathrm{C}$-leucine. Protein translation reactions based on $S f 21$ lysates were incubated for $24 \mathrm{hrs}$ at $30^{\circ} \mathrm{C}, 600 \mathrm{rpm}$ using a thermomixer (Eppendorf, Hamburg, Germany). If required 
translation mixture (TM) of cell-free reactions were further fractionated for analysis. The fractionation was realized by centrifugation at $16,000 \mathrm{~g}$ for $10 \mathrm{~min}$ at $4^{\circ} \mathrm{C}$ in order to separate the ER-derived vesicular fraction (VF) of the cell lysate from the supernatant (SN). The microsomal fraction was suspended in PBS buffer without calcium and magnesium ions for further analysis such as quantification of protein yields. For storage, the total translation mix is snap frozen in liquid nitrogen and stored at $-80^{\circ} \mathrm{C}$.

\section{Quantification of Cell-Free Synthesized Protein Yields:}

Based on the incorporation of ${ }^{14} \mathrm{C}$-leucine in cell-free synthesized proteins, the respective protein yield can be estimated by scintillation measurement. Therefore, $5 \mu \mathrm{L}$ aliquots of each translation mixture were mixed with $3 \mathrm{~mL}$ of a $10 \%(\mathrm{v} / \mathrm{v})$ TCA-2\% $(\mathrm{v} / \mathrm{v})$ casein hydrolysate solution in a glass tube and incubated at $80^{\circ} \mathrm{C}$ for $15 \mathrm{~min}$. Afterwards, samples were chilled on ice for $30 \mathrm{~min}$ and retained on the surface of glass fiber filter papers using a vacuum filtration system. Filter papers were washed twice with 5\% TCA and then vacuum dried with acetone. Dried filters were placed into a scintillation vial, $3 \mathrm{~mL}$ of scintillation cocktail was added and vials were agitated on an orbital shaker for at least $1 \mathrm{hr}$. The scintillation signal was determined using the LS6500 Multi-Purpose scintillation counter. The protein yields were identified based on the obtained scintillation counts and protein specific parameters including molecular mass and amount of leucine. Error bars calculated for the protein yield show the individual standard deviation.

\section{SDS-PAGE and Autoradiography}

The molecular size of radiolabeled, cell-free synthesized protein was analyzed using SDS-PAGE followed by autoradiography. First, $5 \mu \mathrm{L}$ of the respective fraction of a cell-free synthesis reaction including the radiolabeled target protein was subjected to ice-cold acetone. Precipitated protein was separated by centrifugation $\left(16,000 \times \mathrm{g}, 4{ }^{\circ} \mathrm{C}, 10 \mathrm{~min}\right)$ and the protein pellet was dried for at least $30 \mathrm{~min}$ at $45^{\circ} \mathrm{C}$. The dried protein pellet was dissolved in LDS sample buffer with $50 \mathrm{mM}$ DTT and loaded on a pre-casted NuPAGE $10 \%$ Bis-Tris gel. The gel was run at $185 \mathrm{~V}$ for $35 \mathrm{~min}$ according to the manufacturer's protocol. Subsequently, gels were dried at $70{ }^{\circ} \mathrm{C}$, placed on a phosphor screen and radioactively labeled proteins were visualized using a Typhoon Trio + variable mode.

\section{Esterase activity using para-nitrophenol:}

To determine the esterase activity, m-CES2 was translated using Sf21 CECF reaction. $50 \mu$ of total translation mix was first centrifuged at $16,000 \times \mathrm{g}$ for 10 minutes at $4^{\circ} \mathrm{C}$. The microsomal pellet was again washed with Phosphate Buffer Saline (PBS) with no $\mathrm{Ca}^{2+}$ and $\mathrm{Mg}^{2+}$ to remove the native cytosolic carboxylesterases outside the microsomes from the lysate via further centrifugation. The pellet was dissolved in esterase assay buffer containing $20 \mathrm{mM}$ Tris $-\mathrm{HCl}(\mathrm{pH} 8.0), 150 \mathrm{mM} \mathrm{NaCl}$, and $0.01 \%$ Triton X100. Fresh solutions of 4-para-nitrophenylacetate (PNPA) were used as the substrate. $250 \mu \mathrm{l}$ of PNPA substrate solution of $150 \mu \mathrm{M}$ concentration was used to initiate the reaction and the mixture was incubated at $37^{\circ} \mathrm{C}$ for 1 hour. The para-nitro phenol formed after esterase activity was measured using a Mithras Plate reader at $410 \mathrm{~nm}$. No protein was added for blank reactions and the esterase activity was evaluated as percentage of NTC samples. 


\section{Dye loading assays with Fluo-5N AM:}

$50 \mu \mathrm{l}$ of translation mix was first centrifuged $16,000 \mathrm{~g}$ for 10 minutes at $4^{\circ} \mathrm{C}$ to obtain the microsomal pellet. The microsomes were resuspended in ATP based calcium imaging buffer to initiate the SERCA activity. The calcium imaging buffer was composed of $75 \mathrm{mM} \mathrm{KCl}, 20 \mathrm{mM} \mathrm{HEPES}-\mathrm{KOH}, 5 \mathrm{mM} \mathrm{NaN}_{3}$ and $200 \mu \mathrm{M} \mathrm{CaCl}_{2}$ with $\mathrm{pH}$ 7.4. To enhance SERCA activity, $10 \mathrm{mM}$ adenosine 5' triphosphate (ATP), $1 \mathrm{mM}$ $\mathrm{MgCl}_{2}, 0.5 \mathrm{mM}$ dithiothreitol (DTT), $5 \mathrm{mM}$ phosphocreatine (PCr), and $20 \mathrm{U} / \mathrm{mL}$ creatine phosphokinase (CPK). SERCA activity induced $\mathrm{Ca}^{2+}$ loading was performed at $37^{\circ} \mathrm{C}$ for 30 minutes and then stopped by centrifuging and removing the supernatant. The pellet is suspended in $100 \mu$ of Fluo-5N AM dye of concentration $2 \mu \mathrm{M}$ and then incubated at $37^{\circ} \mathrm{C}$ at $500 \mathrm{rpm}$. The reaction is stopped by centrifugation and removal of the dye. Microsomes are further washed with $100 \mu \mathrm{l}$ of PBS to purge the uncleaved Fluo$5 \mathrm{~N}$ AM from the microsomes at $37^{\circ} \mathrm{C}$ for 20 minutes and centrifuged to obtain the microsomal pellet containing only the cleaved dye. Then, the pellet washed and fluorescence removed subsequently was measured in plate reader with $E_{x} 488$ and $E_{m} 515 \mathrm{~nm}$. The blank sample measurements were subtracted and the data is analyzed.

\section{Calcium imaging using confocal laser microscopy}

For all calcium measurements, the microsomes were seeded for attachment on the coverslip coated with poly D lysine Hydrobromide. The coverslips were autoclaved and coated overnight with poly-D-lysine Hydrobromide $(0.1 \mathrm{mg} / \mathrm{ml})$, dried and stored at room temperature. The microsomes were seeded for 1 $\mathrm{h}, 37^{\circ} \mathrm{C}$ and the coverslips were washed with the calcium imaging buffer for removal of unsettled microsomes. A flow chamber fitting the coverslip at the bottom with the aid of vacuum sealing agent was used for all measurements. Argon laser with Alexa 488 at 3\% intensity, maximum gain and 5-6 airy units were used for all measurements using the LSM Meta 510 software (Carl Zeiss Microscopy, GmbH) time series function with a frequency of $30 \mathrm{~s}$ and a $40 \mathrm{X}$ oil immersion objective with numerical aperture 1.3 was used. The data is represented as delta F/F, where delta $F$ represents the difference in fluorescence of microsomes and background. Different regions of interest were selected from each individual experiment from the frame of $512 \mu \mathrm{M} \times 512 \mu \mathrm{M}$ frame for observing whether identical increase or decrease in intensity is present. The slope of bleaching was drift corrected using peak and baseline correction protocol using the OriginPro 2015 software. For comparison of individual experiments with activators and inhibitors, the baseline fluorescence intensity was normalized to 100 a.u. and then increase or decrease in intensity was analyzed. Statistical analysis and plotting graphs were performed either by OriginPro and Microsoft Excel software.

\section{ACKNOWLEDGMENTS:}

This work was supported by German Ministry of Education and Research, BMBF (BMBF, No. 031B0078A). We would like to appreciate Dr. Rita Sachse for her preliminary attempts in this topic during her Ph.D thesis in our lab. We would like to acknowledge Ms. Dana Wenzel (Fraunhofer IZI, Potsdam-Golm, Germany) for technical support, Dr. Lena Thoring and Dr. Marlitt Stech (Fraunhofer IZI, Potsdam-Golm, Germany) for providing their insights and discussion in the cellfree synthesis platform in due course of this research work. We would also like to thank Dr. Michael Kirschbaum for helping us with the imaging platforms. 


\section{AUTHOR CONTIBUTIONS:}

PD and SK have framed the basic idea for this work. D A.W was responsible for production and quality control of cell-free lysates used in this manuscript. AZ, DB and PD have performed experiments. PD, SD and SK have contributed in preparing the manuscript.

\section{CONFLICTS OF INTEREST:}

The authors express no conflicts of interest.

\section{REFERNCES:}

1. Santos R, Ursu O, Gaulton A, Bento AP, Donadi RS, Bologa CG, Karlsson A, Al-Lazikani B, Hersey A, Oprea TI, et al. (2017) A comprehensive map of molecular drug targets. Nat Rev Drug Discov 16: 19-34.

2. Zemella A, Thoring L, Hoffmeister C, Kubick S (2015) Cell-Free Protein Synthesis: Pros and Cons of Prokaryotic and Eukaryotic Systems. ChemBioChem 16: 2420-2431.

3. Lyford LK, Rosenberg RL (1999) Cell-free expression and functional reconstitution of homo-oligomeric alpha7 nicotinic acetylcholine receptors into planar lipid bilayers. J Biol Chem 274: 25675-25681.

4. Falk MM, Buehler LK, Kumar NM, Gilula NB (1997) Cell-free synthesis and assembly of connexins into functional gap junction membrane channels. EMBO J 16: 2703-2716.

5. Dondapati SK, Lübberding H, Zemella A, Thoring L, Wüstenhagen DA, Kubick S (2019) Functional Reconstitution of membrane proteins derived from eukaryotic cell-free systems. Front Pharmacol 10: 917.

6. Dondapati SK, Kreir M, Quast RB, Wüstenhagen DA, Brüggemann A, Fertig N, Kubick S (2014) Membrane assembly of the functional KcsA potassium channel in a vesicle-based eukaryotic cell-free translation system. Biosens Bioelectron 59: 174-183.

7. Hamada S, Tabuchi M, Toyota T, Sakurai T, Hosoi T, Nomoto T, Nakatani K, Fujinami M, Kanzaki R (2014) Giant vesicles functionally expressing membrane receptors for an insect pheromone. Chem Commun (Camb) 50: $2958-2961$.

8. Jarecki BW, Makino S, Beebe ET, Fox BG, Chanda B (2013) Function of Shaker potassium channels produced by cell-free translation upon injection into Xenopus oocytes. Sci Rep 3: 1040.

9. Umigai N, Sato Y, Mizutani A, Utsumi T, Sakaguchi M, Uozumi N (2003) Topogenesis of two transmembrane type K+ channels, Kir 2.1 and KcsA. J Biol Chem 278: 40373-40384.

10. Samtleben S, Jaepel J, Fecher C, Andreska T, Rehberg M, Blum R (2013) Direct imaging of ER calcium with targeted-esterase induced dye loading (TED). J Vis Exp e50317.

11. Blum R, Petersen OH, Verkhratsky A (2010) Ca2+ Imaging of Intracellular Organelles: Endoplasmic Reticulum. In Verkhratsky A, Petersen OH (eds.), Calcium Measurement Methods pp 147-167. Humana Press, Totowa, NJ.

12. McMullen DC, Kean WS, Verma A, Cole JT, Watson WD (2012) A microplate technique to simultaneously assay calcium accumulation in endoplasmic reticulum and SERCA release of inorganic phosphate. Biol Proced Online 14: 4.

13. Parsons JT, Churn SB, DeLorenzo RJ (1997) Ischemia-induced inhibition of calcium uptake into rat brain microsomes mediated by Mg2+/Ca2+ ATPase. J Neurochem 68: 1124-1134.

14. Moore L, Davenport GR, Landon EJ (1976) Calcium uptake of a rat liver microsomal subcellular fraction in response to in vivo administration of carbon tetrachloride. J Biol Chem 251: 1197-1201.

15. Wernet W, Sieber M, Landgraf W, Hofmann F (1988) Rabbit skeletal muscle microsomes contain two distinct phenylalkylamine-binding sites. European Journal of Biochemistry 172: 233-238.

16. Zemella A, Grossmann S, Sachse R, Sonnabend A, Schaefer M, Kubick S (2017) Qualifying a eukaryotic cellfree system for fluorescence based GPCR analyses. Sci Rep 7(1):3740.

17. Brödel AK, Sonnabend A, Roberts LO, Stech M, Wüstenhagen DA, Kubick S (2013) IRES-Mediated Translation of Membrane Proteins and Glycoproteins in Eukaryotic Cell-Free Systems. PLoS One 8(12): e82234

18. Thoring L, Dondapati SK, Stech M, Wüstenhagen DA, Kubick S (2017) High-yield production of "difficult-to- 
express" proteins in a continuous exchange cell-free system based on CHO cell lysates. Sci Rep 7: 1-15.

19. Stech M, Quast RB, Sachse R, Schulze C, Wüstenhagen DA, Kubick S (2014) A continuous-exchange cell-free protein synthesis system based on extracts from cultured insect cells. PLoS ONE 9: e96635.

20. Quast RB, Sonnabend A, Stech M, Wüstenhagen DA, Kubick S (2016) High-yield cell-free synthesis of human EGFR by IRES-mediated protein translation in a continuous exchange cell-free reaction format. Sci Rep 6: 30399.

21. Gilham D, Lehner R (2005) Techniques to measure lipase and esterase activity in vitro. Methods 36: 139-147.

22. Tildon JT, Ogilvie JW (1972) The Esterase Activity of Bovine Mercaptalbumin: the reaction of the protein with p-nitrophenyl acetate. J Biol Chem 247: 1265-1271.

23. Nascimento ARB do, Fresia P, Cônsoli FL, Omoto C (2015) Comparative transcriptome analysis of lufenuronresistant and susceptible strains of Spodoptera frugiperda (Lepidoptera: Noctuidae). BMC Genomics 16: 985.

24. Giraudo M, Hilliou F, Fricaux T, Audant P, Feyereisen R, Le Goff G (2015) Cytochrome P450s from the fall armyworm (Spodoptera frugiperda): responses to plant allelochemicals and pesticides. Insect Mol Biol 24: 115-128.

25. Castillo B, Pörzgen P, Penner R, Horgen FD, Fleig A (2010) Development and Optimization of a HighThroughput Bioassay for TRPM7 Ion Channel Inhibitors. J Biomol Screen 15: 498-507.

26. Launikonis BS, Stephenson DG (1999) Effects of $\beta$-escin and saponin on the transverse-tubular system and sarcoplasmic reticulum membranes of rat and toad skeletal muscle. Pflügers Arch 437: 955-965.

27. Paredes RM, Etzler JC, Watts LT, Lechleiter JD (2008) Chemical Calcium Indicators. Methods 46: 143-151.

28. Shannon Thomas R., Guo Tao, Bers Donald M. (2003) Ca2+ Scraps. Circulation Research 93: 40-45.

29. Rehberg M, Lepier A, Solchenberger B, Osten P, Blum R (2008) A new non-disruptive strategy to target calcium indicator dyes to the endoplasmic reticulum. Cell Calcium 44: 386-399.

30. Caramelo JJ, Parodi AJ (2008) Getting in and Out from Calnexin/Calreticulin Cycles. J Biol Chem 283: 1022110225.

31. Kunitomo Y, Terentyev D (2011) How to stop the fire? Control of $\mathrm{Ca}^{2+}$-induced $\mathrm{Ca}^{2+}$ release in cardiac muscle. J Physiol (Lond) 589: 5899-5900.

32. Autry JM, Jones LR (1997) Functional Co-expression of the Canine Cardiac Ca2+Pump and Phospholamban in Spodoptera frugiperda (Sf21) Cells Reveals New Insights on ATPase Regulation. J Biol Chem 272: 1587215880.

33. Winters DL, Autry JM, Svensson B, Thomas DD (2008) Interdomain Fluorescence Resonance Energy Transfer in SERCA Probed by Cyan-Fluorescent Protein Fused to the Actuator Domain. Biochemistry 47: 4246-4256.

34. Oliver AE, Baker GA, Fugate RD, Tablin F, Crowe JH (2000) Effects of temperature on calcium-sensitive fluorescent probes. Biophys J 78: 2116-2126.

35. Missiaen L, Wuytack F, Kanmura Y, Van Belle H, Wynants J, Minten J, Casteels R (1989) Measurement of microsomal ATPase activities: a comparison between the inorganic phosphate-release assay and the NADHcoupled enzyme assay. Biochimica et Biophysica Acta (BBA) - General Subjects 990: 40-44.

36. Meldolesi J, Pozzan T (1998) The endoplasmic reticulum Ca2+ store: a view from the lumen. Trends Biochem Sci 23: 10-14.

37. Michalak M, Robert Parker JM, Opas M (2002) Ca2+ signaling and calcium binding chaperones of the endoplasmic reticulum. Cell Calcium 32: 269-278.

38. Damiani E, Heilmann C, Salvatori S, Margreth A (1989) Characterization of high-capacity low-affinity calcium binding protein of liver endoplasmic reticulum: calsequestrin-like and divergent properties. Biochem Biophys Res Commun 165: 973-980.

39. Uehara A, Murayama T, Yasukochi M, Fill M, Horie M, Okamoto T, Matsuura Y, Uehara K, Fujimoto T, Sakurai $\mathrm{T}$, et al. (2017) Extensive Ca2+ leak through $\mathrm{K} 4750 \mathrm{Q}$ cardiac ryanodine receptors caused by cytosolic and luminal Ca2+ hypersensitivity. J Gen Physiol 149: 199-218.

40. Camors E, Valdivia HH (2014) CaMKII regulation of cardiac ryanodine receptors and inositol triphosphate receptors. Front Pharmacol 5:101.

41. Fill M, Copello JA (2002) Ryanodine Receptor Calcium Release Channels. Physiological Reviews 82: 893-922.

42. Vázquez-Martínez O, Cañedo-Merino R, Díaz-Muñoz M, Riesgo-Escovar JR (2003) Biochemical characterization, distribution and phylogenetic analysis of Drosophila melanogaster ryanodine and IP3 receptors, and thapsigargin-sensitive Ca2+ ATPase. Journal of Cell Science 116: 2483-2494. 
43. Vetter I, Wyse BD, Monteith GR, Roberts-Thomson SJ, Cabot PJ (2006) The $\mu$ Opioid Agonist Morphine Modulates Potentiation of Capsaicin-Evoked TRPV1 Responses through a Cyclic AMP-Dependent Protein Kinase a Pathway: Molecular Pain.

44. Grant ER, Dubin AE, Zhang S-P, Zivin RA, Zhong Z (2002) Simultaneous Intracellular Calcium and Sodium Flux Imaging in Human Vanilloid Receptor 1 (VR1)-Transfected Human Embryonic Kidney Cells: A Method to Resolve Ionic Dependence of VR1-Mediated Cell Death. J Pharmacol Exp Ther 300: 9-17.

45. Senning EN, Collins MD, Stratiievska A, Ufret-Vincenty CA, Gordon SE (2014) Regulation of TRPV1 lon Channel by Phosphoinositide (4,5)-Bisphosphate the role of membrane asymmetry. J Biol Chem 289: 10999-11006.

46. Brauchi S, Orta G, Mascayano C, Salazar M, Raddatz N, Urbina H, Rosenmann E, Gonzalez-Nilo F, Latorre R (2007) Dissection of the components for PIP2 activation and thermosensation in TRP channels. PNAS 104: 10246-10251.

47. Rohacs T, Thyagarajan B, Lukacs V (2008) Phospholipase C mediated modulation of TRPV1 channels. Mol Neurobiol 37: 153-163.

48. Kolay S, Basu U, Raghu P (2019) Control of diverse sub-cellular processes by a single multi-functional lipid phosphatidylinositol 4,5-bisphosphate [PI(4,5)P2]. Biochem J 473: 1681-1692.

49. Hammond GRV, Schiavo G, Irvine RF (2009) Immunocytochemical techniques reveal multiple, distinct cellular pools of Ptdlns4P and Ptdlns(4,5)P(2). Biochem J 422: 23-35.

50. Schramp M, Hedman A, Li W, Tan X, Anderson R (2012) PIP kinases from the cell membrane to the nucleus. Subcell Biochem 58: 25-59.

51. Dusza HM, Cenijn PH, Kamstra JH, Westerink RHS, Leonards PEG, Hamers T (2018) Effects of environmental pollutants on calcium release and uptake by rat cortical microsomes. NeuroToxicology 69: 266-277.

52. Palmer AE, Jin C, Reed JC, Tsien RY (2004) Bcl-2-mediated alterations in endoplasmic reticulum Ca2+ analyzed with an improved genetically encoded fluorescent sensor. Proc Natl Acad Sci USA 101: 17404-17409.

53. Montella IR, Schama R, Valle D (2012) The classification of esterases: an important gene family involved in insecticide resistance - A review. Memórias do Instituto Oswaldo Cruz 107: 437-449.

54. Cui F, Li M-X, Chang H-J, Mao Y, Zhang H-Y, Lu L-X, Yan S-G, Lang M-L, Liu L, Qiao C-L (2015) Carboxylesterasemediated insecticide resistance: Quantitative increase induces broader metabolic resistance than qualitative change. Pestic Biochem Physiol 121: 88-96.

55. Wheelock CE, Phillips BM, Anderson BS, Miller JL, Miller MJ, Hammock BD (2008) Applications of carboxylesterase activity in environmental monitoring and toxicity identification evaluations (TIEs). Rev Environ Contam Toxicol 195: 117-178.

56. Laizure SC, Herring V, Hu Z, Witbrodt K, Parker RB (2013) The role of human carboxylesterases in drug metabolism: have we overlooked their importance? Pharmacotherapy 33: 210-222.

\section{FIGURE LEGENDS:}

Fig 1: Cell-free protein synthesis of $h$ TRPV1 and $m$ CES2 a) Protein yields of $m$ CES2 by scintillation counting via CECF reaction for $24 \mathrm{~h}, 30^{\circ} \mathrm{C}$ in Sf21 system ; b) Protein yields of hTRPV1 by scintillation counting via CECF reaction for $24 \mathrm{~h}, 30^{\circ} \mathrm{C}$ in Sf21 system c) Template design of $m$ CES2 and $h$ TRPV1, MELmelittin signal sequence, T7 P - T7 promoter, T7 T - T7 terminator, IRES- Cricket paralysis virus Internal Ribosome Entry Site, d) Autoradiogram of proteins run on SDS MES

Fig 2: Esterase activity using PNPA a) Schematic representation of cell-free synthesis of mCES2 ; $b$ ) Substrate concentration dependent esterase activity plot of $m C E S 2,37^{\circ} \mathrm{C}, 60 \mathrm{ng}$ of $\mathrm{mCES} 2, \mathrm{n}=3$; c) Esterase activity of $m \mathrm{CES} 2 \mathrm{using}$ PNPA in the microsomes, $37^{\circ} \mathrm{C}, 60 \mathrm{~min}, 100 \mathrm{ng}$ in $0.3 \mathrm{mM}$ PNPA, $\mathrm{n}=6$; d) Time and enzyme concentration dependent plot of $m \mathrm{CES} 2,37^{\circ} \mathrm{C}$ with $0.3 \mathrm{mM}$ PNPA , $\mathrm{n}=3$.

Fig 3: Calcium dye loading experiments a) Illustration of calcium dye loading in $m$ CES2 microsomes, b) Esterase activity performed with $200 \mathrm{ng}$ of $m$ CES2 each in $100 \mu \mathrm{l}$ of $5 \mu \mathrm{M}$ Fluo $5 \mathrm{~N}-\mathrm{AM}, 37^{\circ} \mathrm{C}, 60 \mathrm{~min}, \mathrm{n}=$ 5 ; c) Time dependent esterase activity with $100 \mathrm{ng}$ of $m \mathrm{CES} 2$ each in $100 \mu \mathrm{l}$ of $5 \mu \mathrm{M}$ Fluo $5 \mathrm{~N}-\mathrm{AM}, 37^{\circ} \mathrm{C}, \mathrm{n}$ 
= 2; d) Fluo 5N-AM concentration dependent activity with $100 \mathrm{ng}$ of $m$ CES2 protein each in $100 \mu \mathrm{l}$ reaction, 60 minutes, $37^{\circ} \mathrm{C}, \mathrm{n}=2$.

Fig 4: Direct calcium imaging using $m$ CES2 microsomes a) $K_{d}$ evaluation of Fluo $5 \mathrm{~N}-\mathrm{AM}$ in the $S f 21$ microsomes using $10 \mu \mathrm{M}$ ionomycin plus varying concentration of calcium, $n=4$, the data is represented as mean + /- S.E.M in the plot of $\mathrm{I} / \mathrm{I}_{\max }$ and $\mathrm{Ca}^{2+}$ concentration; b) SERCA pump activity in microsomes at room temperature with $10 \mathrm{mM}$ ATP added at $3 \mathrm{~min}$ and measured for 30 minutes, $n=5$. ATP induced calcium loading into the $m$ CES2 microsomes was observed. The measurement was done using general calcium assay buffer plus the ATP regenerating system, $1 \mathrm{mM} \mathrm{Mg}{ }^{2+}$ and $1 \mathrm{mM} \mathrm{DTT}$; the data is represented as mean +/- S.E.M. The data before adding ATP is normalized to 0 . c) Calcium levels comparison between ATP induced $\mathrm{Ca}^{2+}$ loaded and non-loaded microsomes at $37^{\circ} \mathrm{C}$ for 1 hour, $\mathrm{n}=5$ each, the data is represented as box plot with max and min; d) Caffeine induced calcium release in $m$ CES2 microsomes via ryanodine receptor (RyR2) activation, $\mathrm{n}=6$ each for $10 \mathrm{mM}$ and $100 \mu \mathrm{M}$ caffeine. The data is represented as $\triangle \mathrm{F} / \mathrm{F} * 100$ of Fluo $5 \mathrm{~N}$-AM. Calcium was loaded in the $m$ CES2 microsomes with ATP for $60 \mathrm{~min}, 37^{\circ} \mathrm{C}$ prior to caffeine experiments, e) Representative confocal images of I, II and III from different states of graph f); f) Representative graph of calcium concentration determination using $\mathrm{Ca}^{2+}$ free $+5 \mathrm{mM}$ EGTA and $10 \mathrm{mM} \mathrm{Ca}^{2+}$ in the presence of $10 \mu \mathrm{M}$ ionomycin.

Fig 5: Functional assessment of cell-free synthesized $h$ TRPV1 a) Illustration of calcium dynamics in microsomes expressed with $h$ TRPV1 and $m$ CES2; b) Comparison plot of $h$ TRPV1- $m$ CES 2 and $m$ CES 2 microsomes for capsaicin (CAP) induced $\mathrm{Ca}^{2+}$ release from microsomes, $\mathrm{n}=6$ each. $10 \mu \mathrm{M}$ capsaicin was used at $5 \mathrm{~min}$ and the release was monitored further for 10 minutes. No $\mathrm{Ca}^{2+}$ release was observed in the $m$ CES2 microsomes; c) Capsazepine mediated inhibition of calcium release caused by capsaicin in $h$ TRPV1-mCES2 microsomes, $200 \mathrm{nM}$ CAP and $20 \mu \mathrm{M} \mathrm{CPZ}$ were used, $\mathrm{n}=6$ each. All samples in c) and d) were calcium loaded for $60 \mathrm{~min}, 37^{\circ} \mathrm{C}$ using ATP before start of capsaicin and capsazepine studies. All data in b) and c) is represented as $\triangle F / F^{*} 100$ of baseline before adding the stimulant; d) Dose dependent response of capsaicin in $h$ TRPV1-mCES2 microsomes, $\mathrm{n}=4$ to 7 per each data point. 
a)

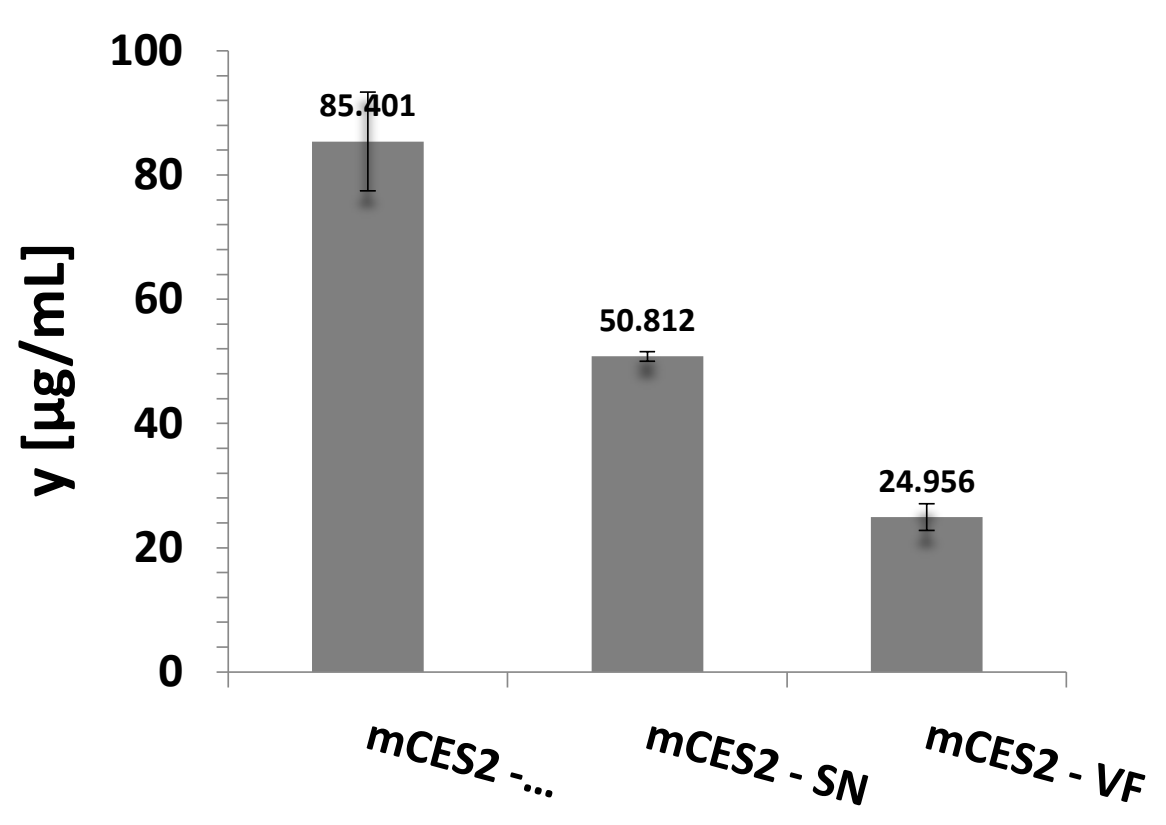

b)

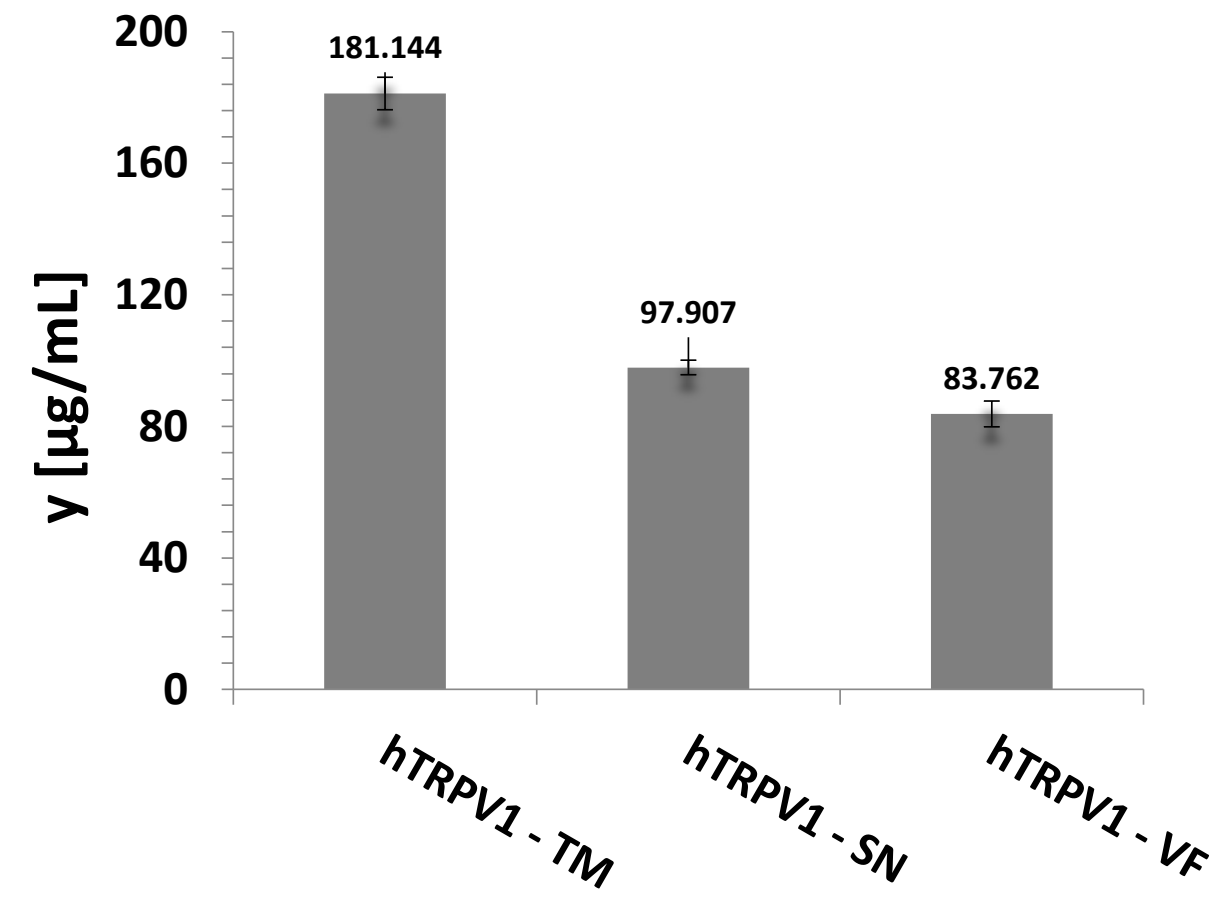

c)

d)

$\begin{array}{lll}m \text {-CES2 } & \text { mCES2 } & \text { NTC } \\ & +h T R P V 1 & \end{array}$

$\begin{array}{lllllllllll}1 & 2 & 3 & 1 & 2 & 3 & 1 & 2 & 3 & \mathrm{kDa}\end{array}$ $\rightarrow \infty \rightarrow$

hTRPV1 -

mCES2 $\rightarrow-0$ 
a)

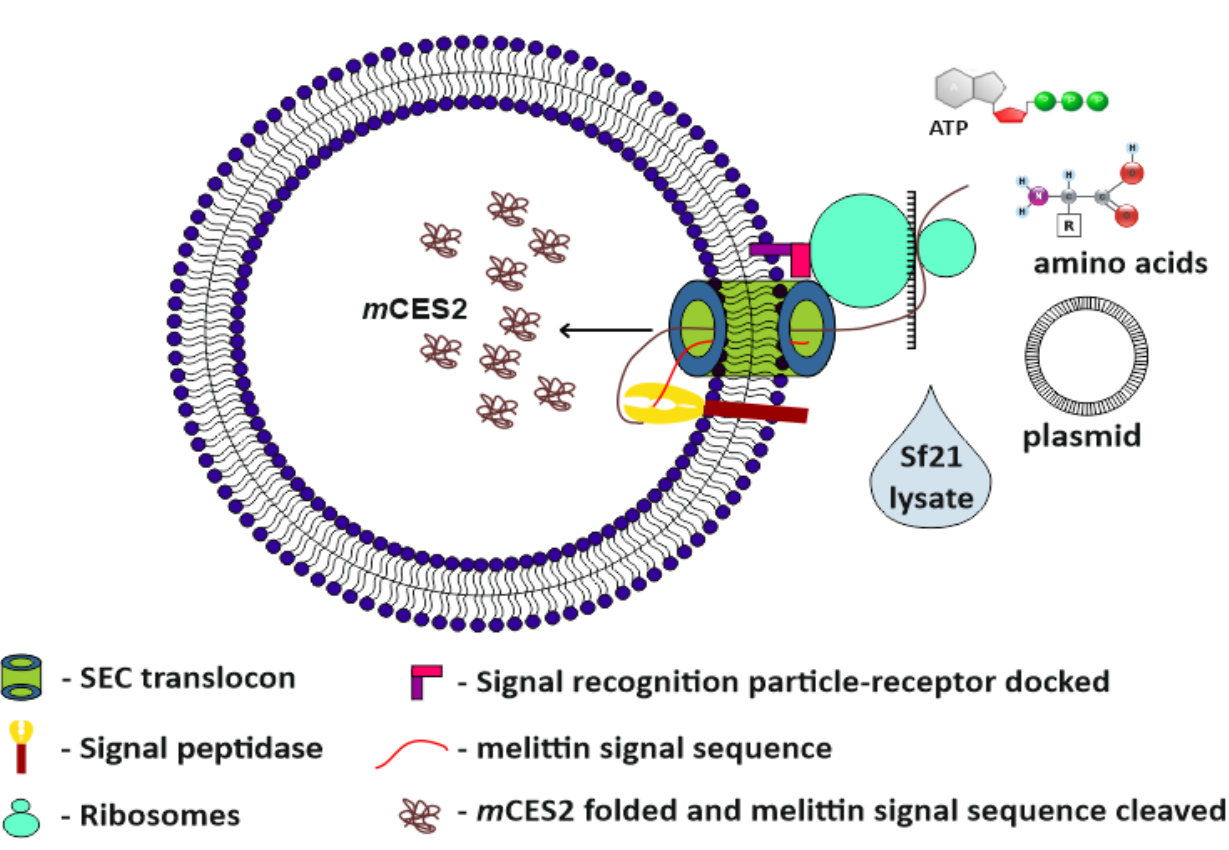

b)

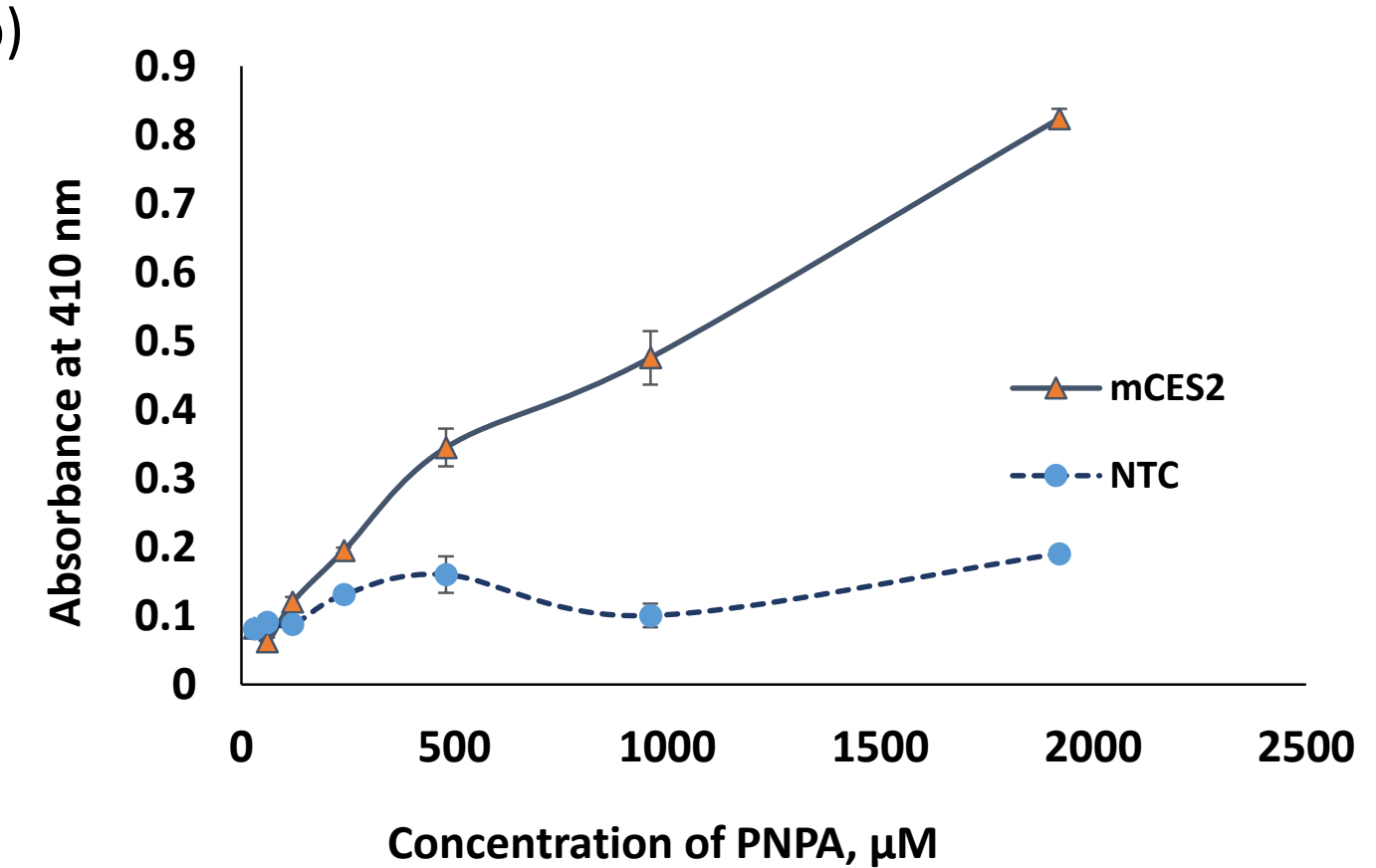

c)

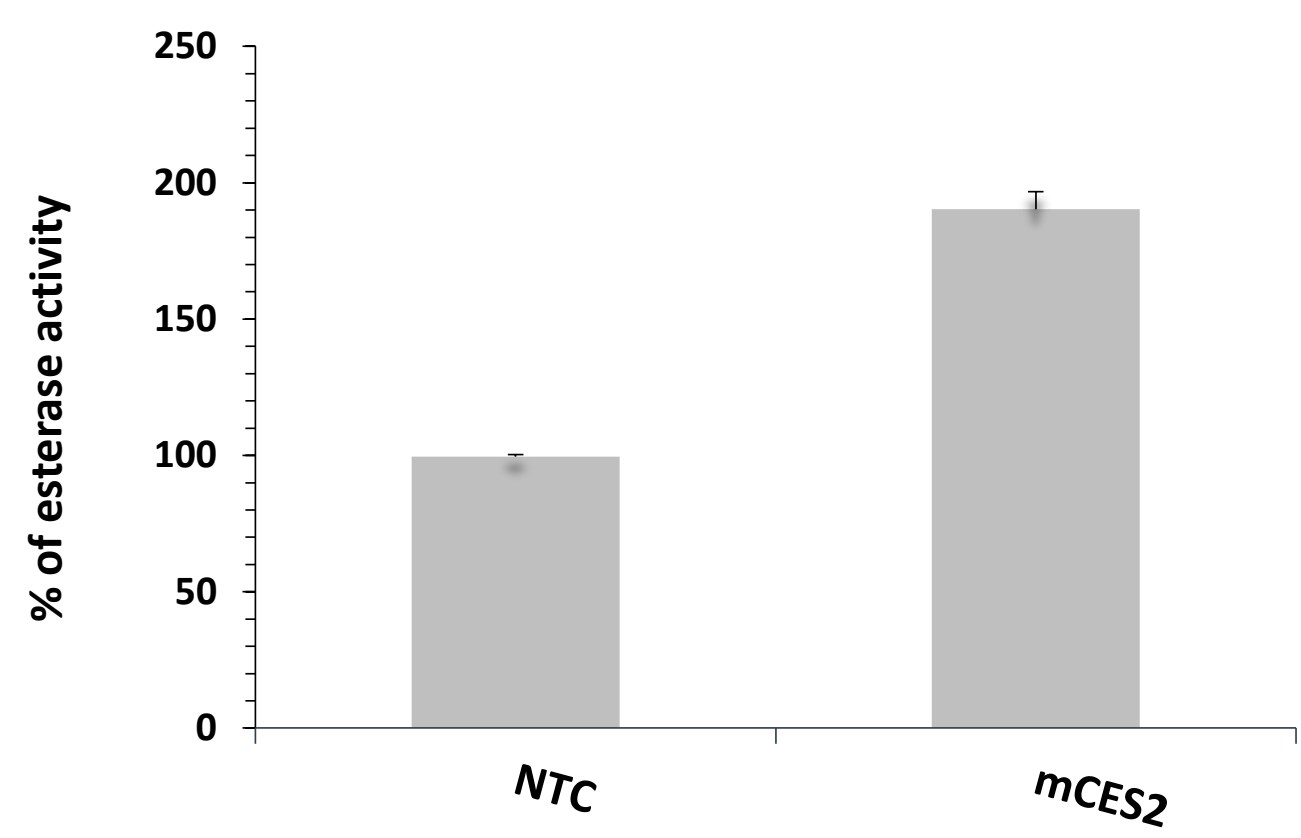

d)

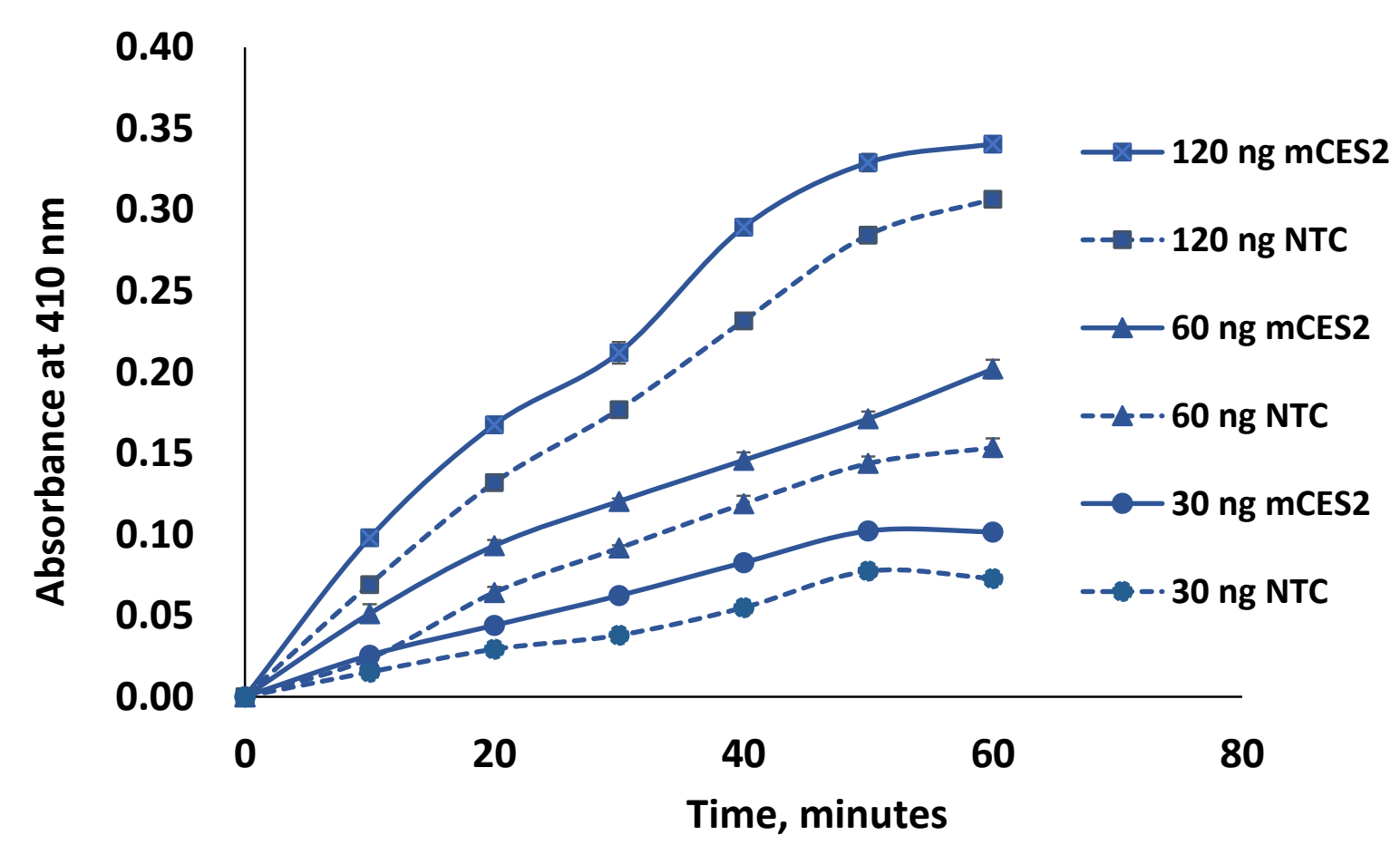


a)

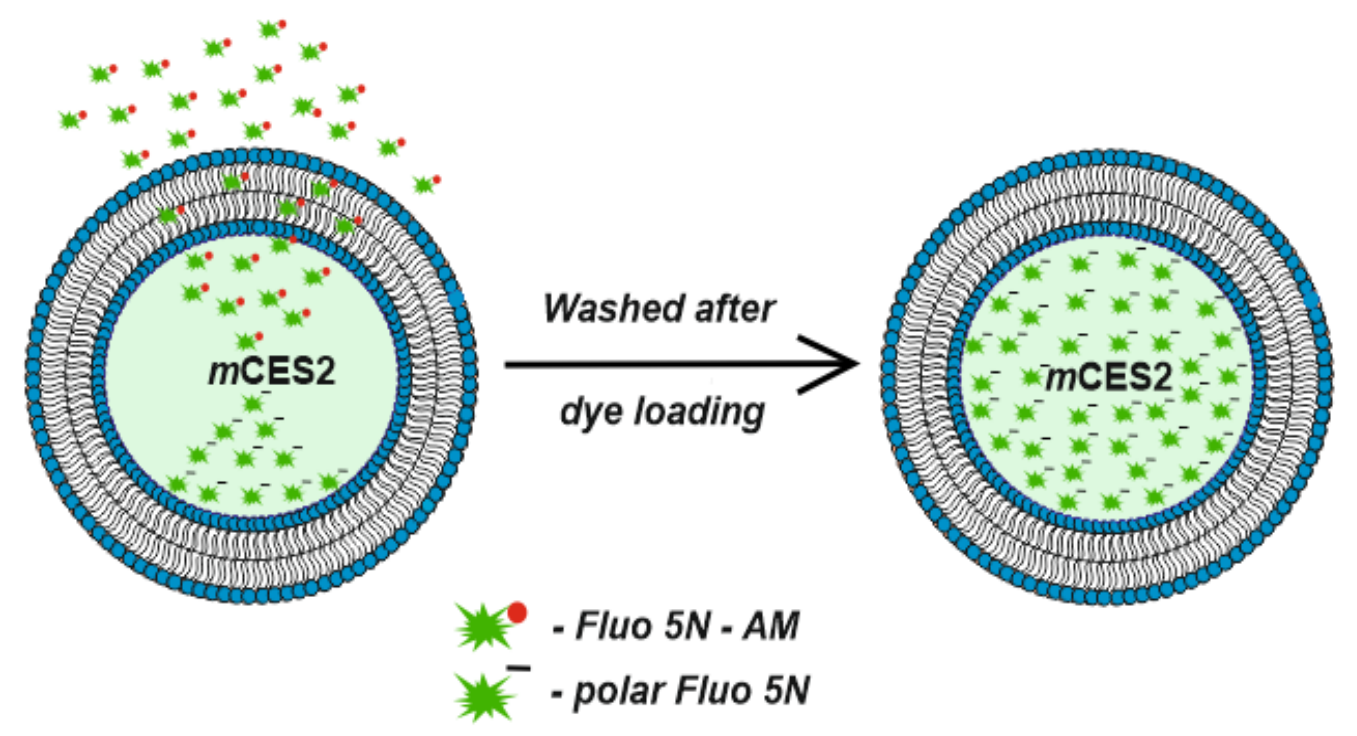

b)

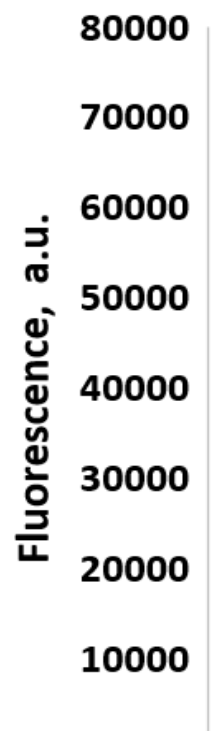

0 c)

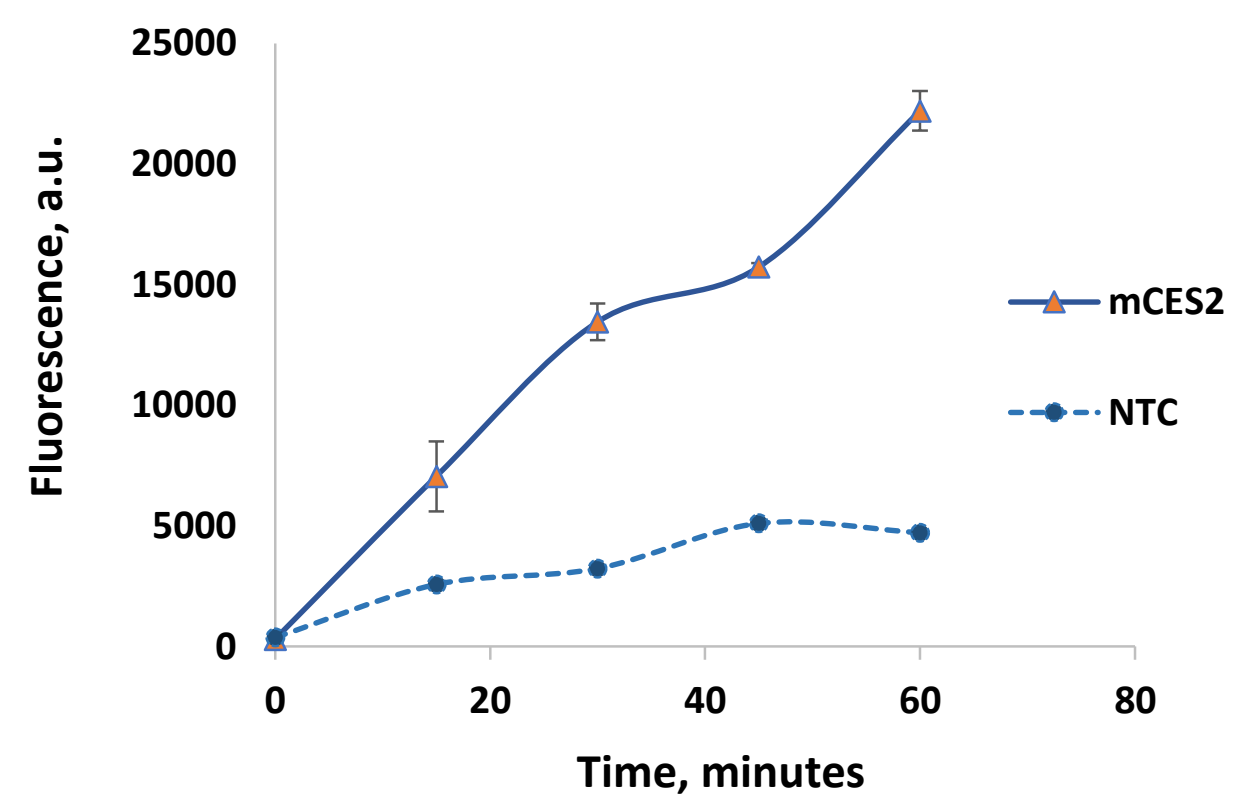

d)

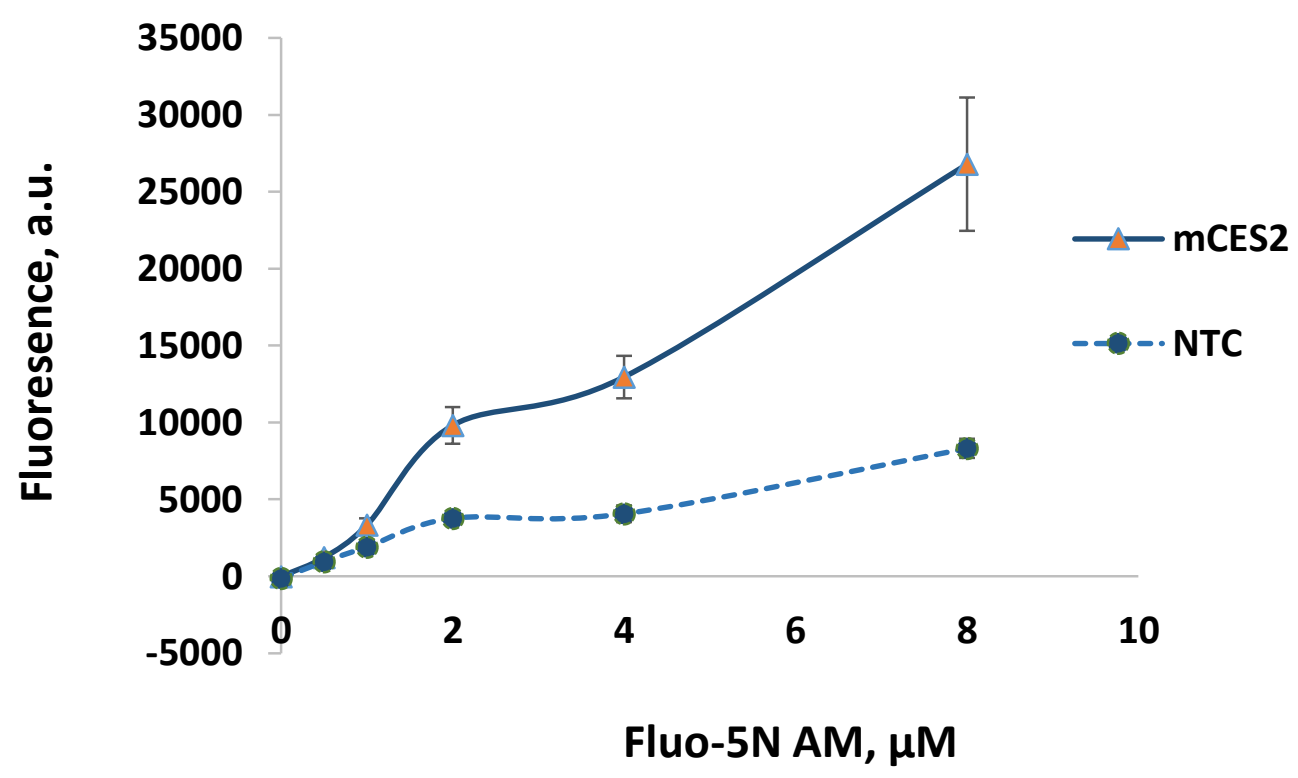


a)
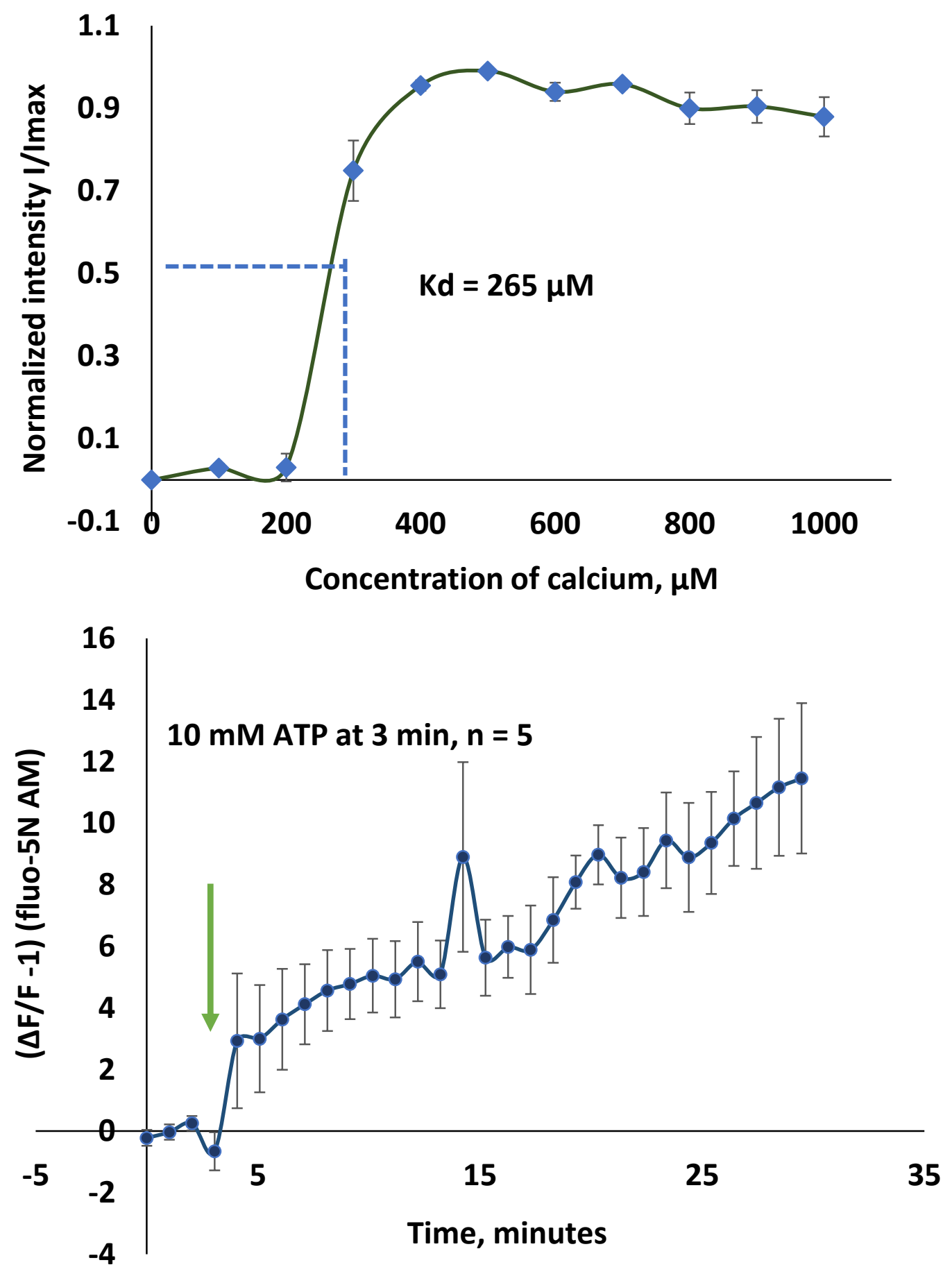

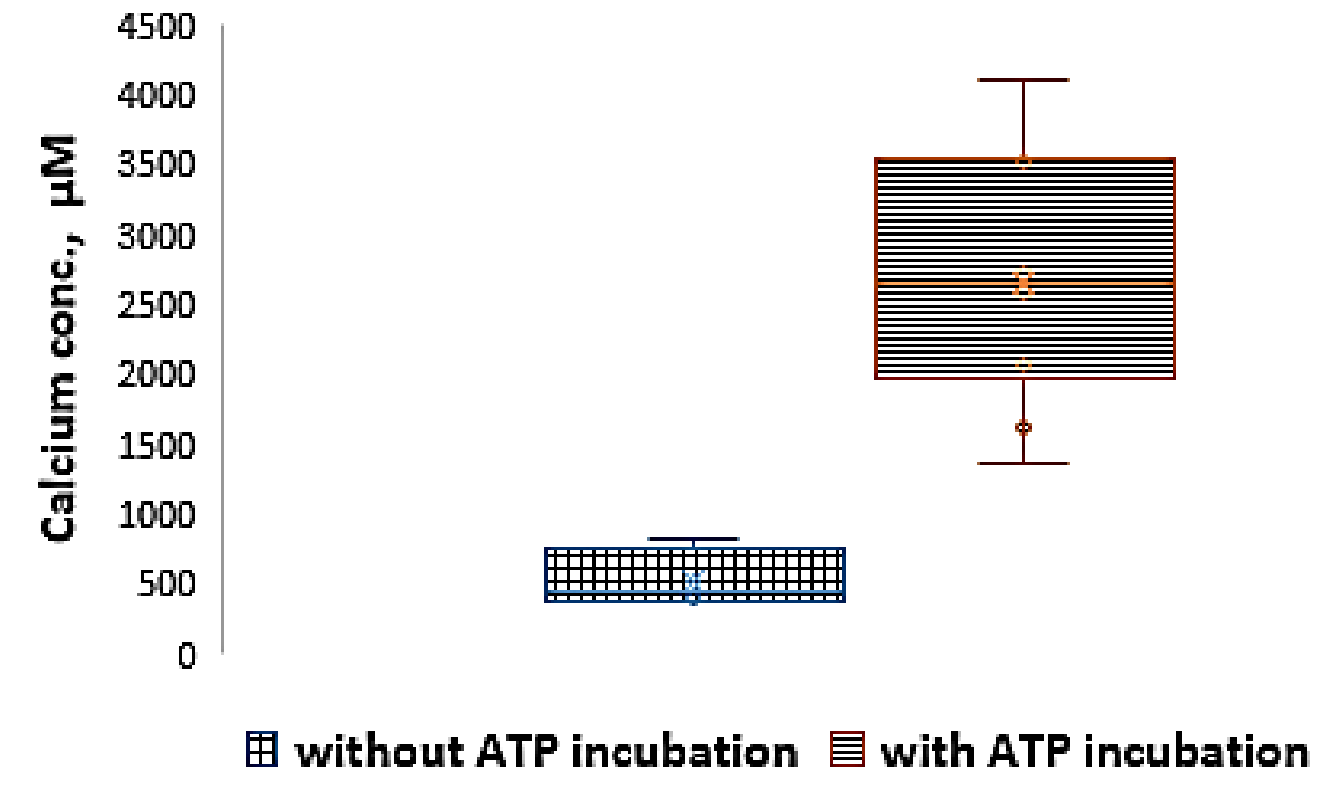

d)

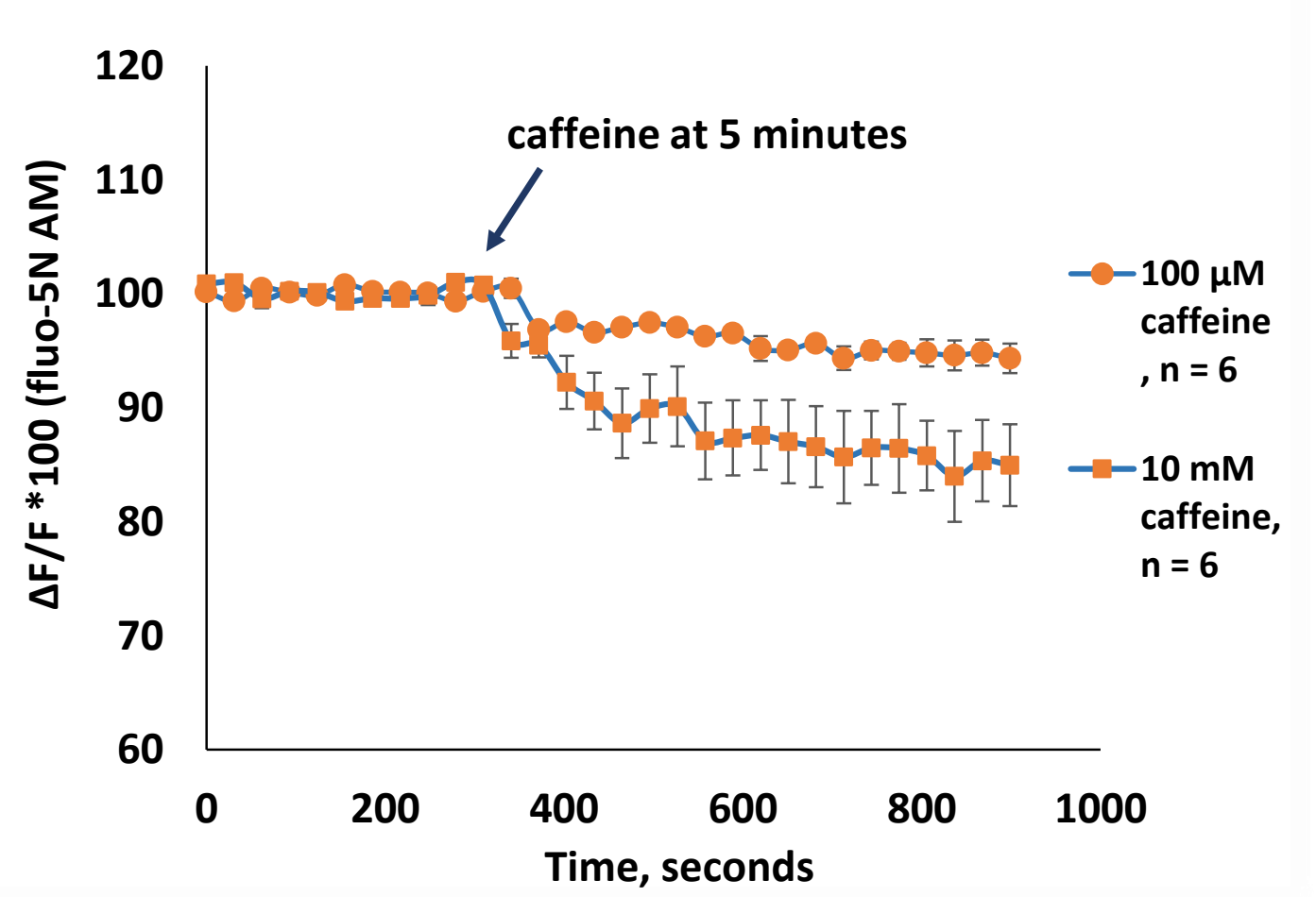

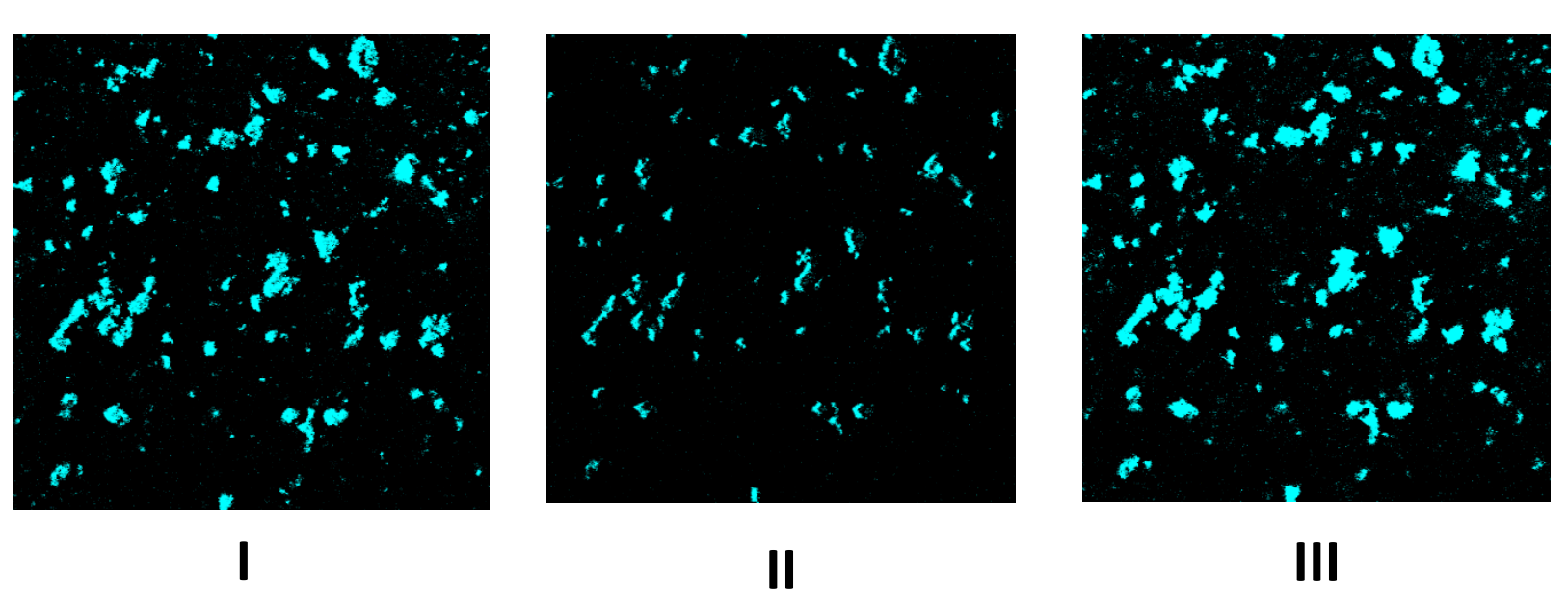

$\mathrm{Ca}^{2+}$ free + 5 mM EGTA

III

f)

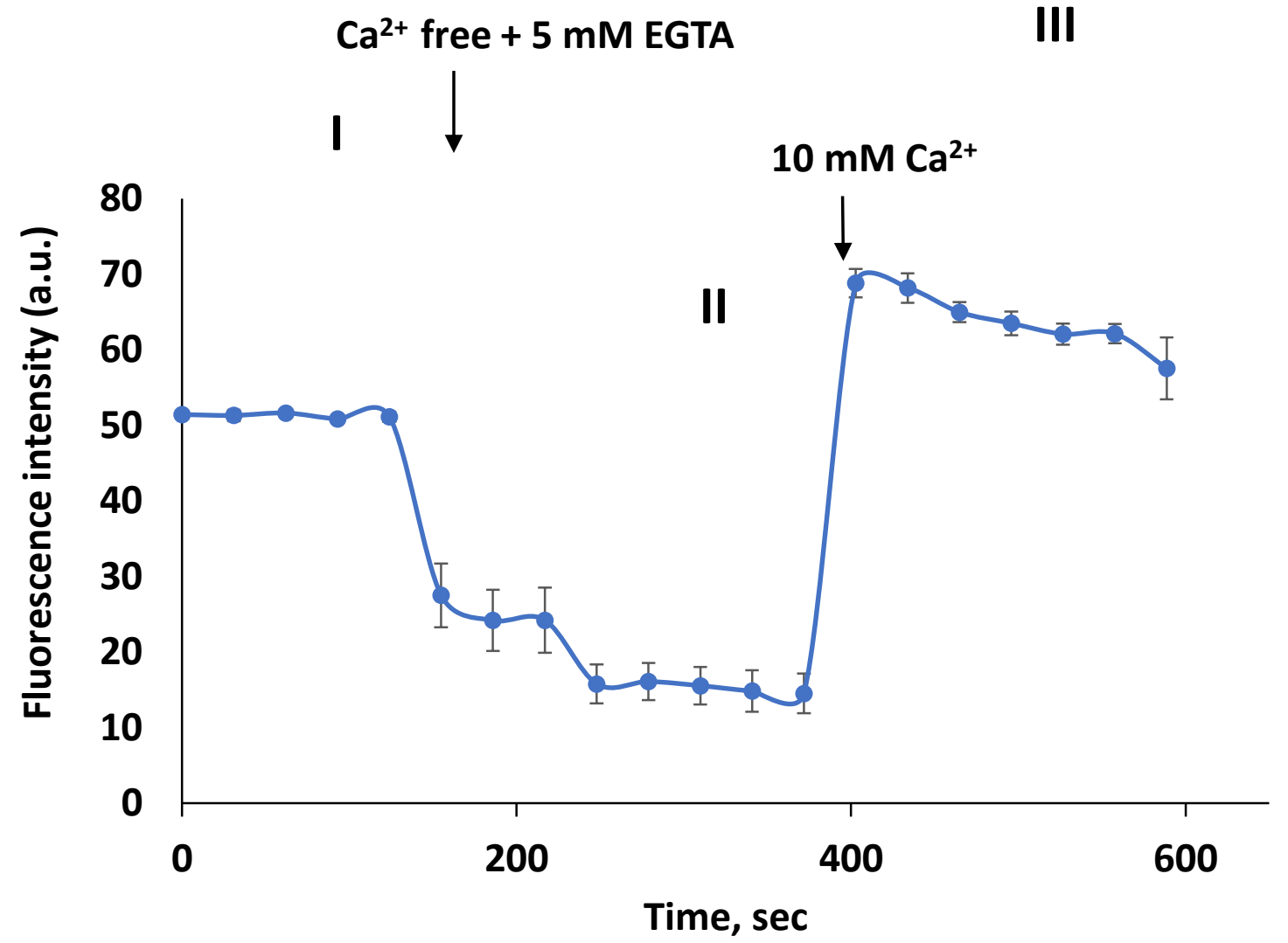


a)

b)

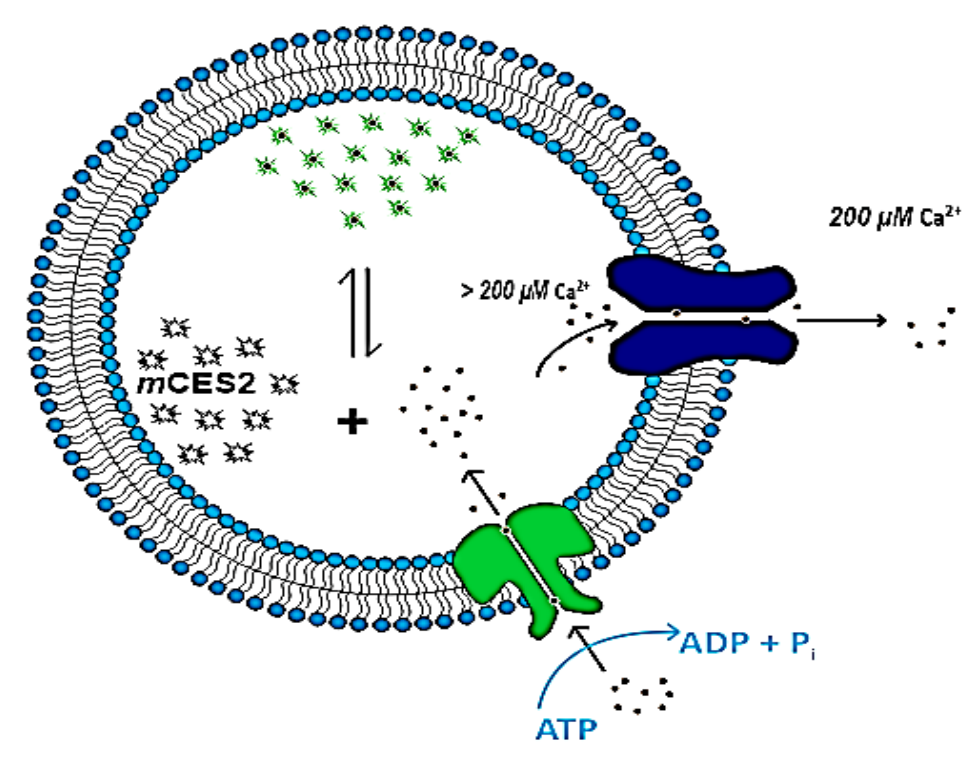

20 - $h$ TRPV1

$25-\mathrm{Ca}^{2+}$ atPase

- Fluo 5N

- Fluo $5 \mathrm{~N}$ bound to $\mathrm{Ca}^{2+}$ c)

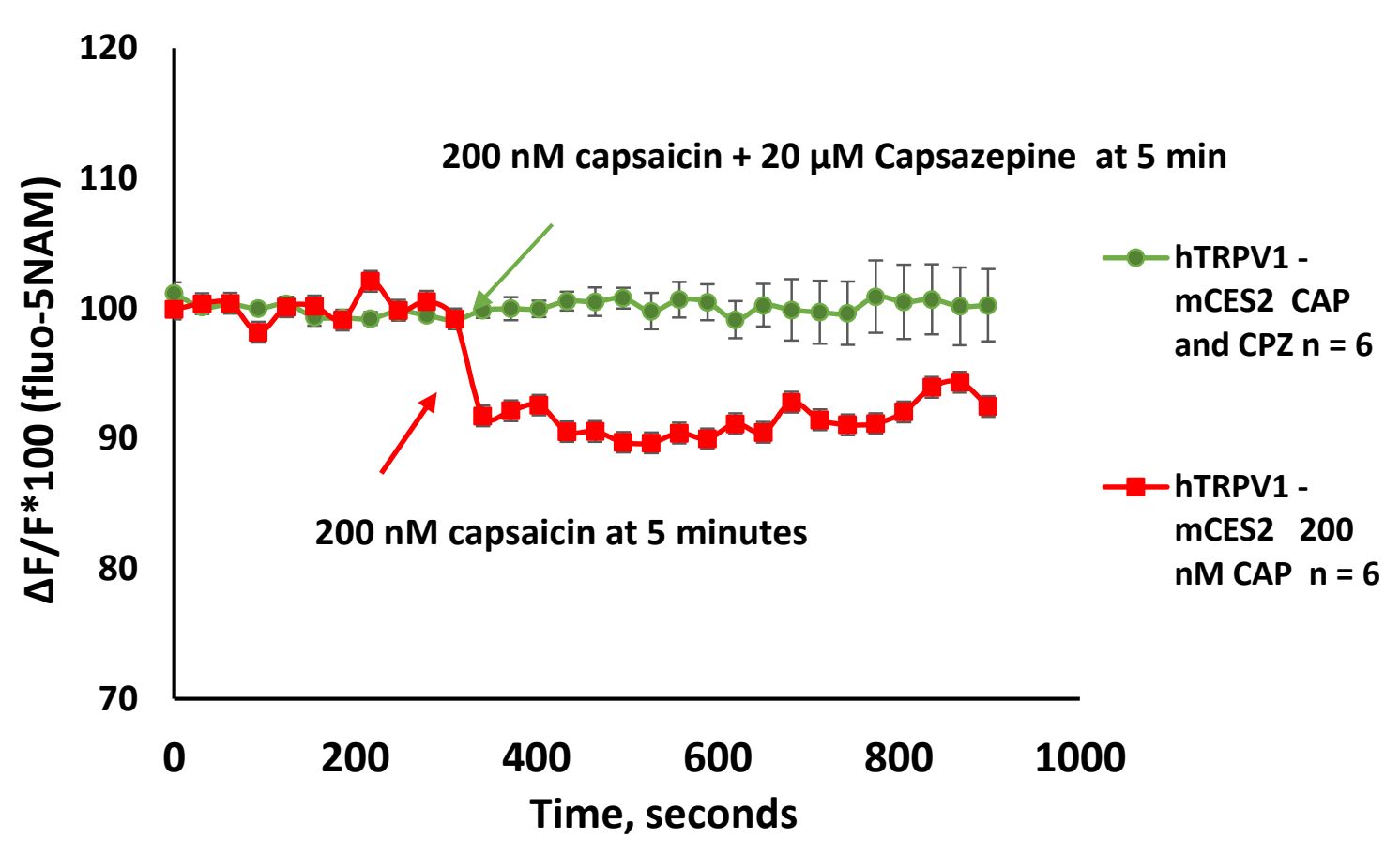

d)
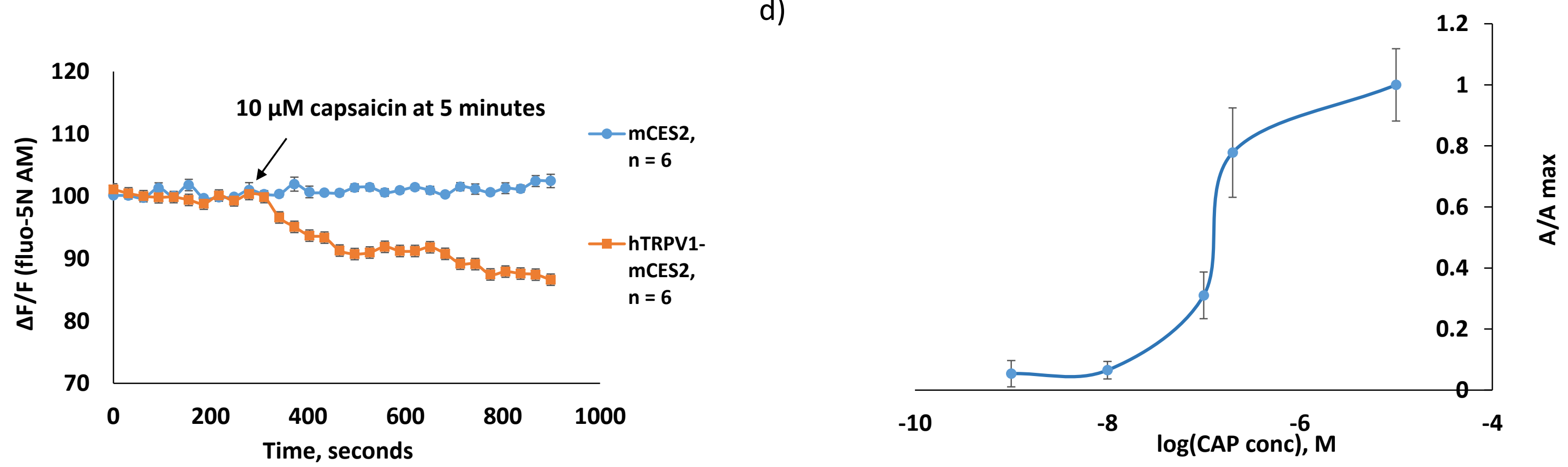
bioRxiv preprint doi: https://doi.org/10.1101/2020.03.05.978247; this version posted March 6, 2020. The copyright holder for this preprint (which was not certified by peer review) is the author/funder, who has granted bioRxiv a license to display the preprint in perpetuity. It is made available under aCC-BY 4.0 International license.

\begin{tabular}{|c|c|c|c|c|c|c|}
\hline & \multicolumn{6}{|c|}{$m$ CES2 samples } \\
\hline & \multicolumn{2}{|c|}{$30 \mathrm{ng}$} & \multicolumn{2}{|c|}{$60 \mathrm{ng}$} & \multicolumn{2}{|c|}{$120 \mathrm{ng}$} \\
\hline Time (sec) & average & S.E.M & average & S.E.M & average & S.E.M \\
\hline 0 & 0.000000 & 0.000000 & 0.000000 & 0.000000 & 0.000000 & 0.000000 \\
\hline 10 & 0.025467 & 0.000720 & 0.051200 & 0.002265 & 0.097800 & 0.003859 \\
\hline 20 & 0.043867 & 0.001785 & 0.093000 & 0.002868 & 0.167533 & 0.004907 \\
\hline 30 & 0.062200 & 0.003559 & 0.120333 & 0.001785 & 0.211867 & 0.006706 \\
\hline 40 & 0.082533 & 0.000720 & 0.145667 & 0.013411 & 0.289200 & 0.003266 \\
\hline 50 & 0.102000 & 0.001633 & 0.171267 & 0.014350 & 0.329000 & 0.005354 \\
\hline \multirow[t]{3}{*}{60} & 0.101467 & 0.000544 & 0.201867 & 0.014631 & 0.340467 & 0.001361 \\
\hline & \multicolumn{6}{|c|}{ NTC samples } \\
\hline & \multicolumn{2}{|c|}{$30 \mathrm{ng}$} & \multicolumn{2}{|c|}{$60 \mathrm{ng}$} & \multicolumn{2}{|c|}{$120 \mathrm{ng}$} \\
\hline Time (sec) & average & S.E.M & average & S.E.M & average & S.E.M \\
\hline 0 & 0.000000 & 0.000000 & 0.000000 & 0.000000 & 0.000000 & 0.000000 \\
\hline 10 & 0.015133 & 0.002880 & 0.023467 & 0.005761 & 0.069133 & 0.001515 \\
\hline 20 & 0.029200 & 0.001247 & 0.064200 & 0.003399 & 0.131867 & 0.004481 \\
\hline 30 & 0.037867 & 0.003954 & 0.091533 & 0.001785 & 0.176867 & 0.003839 \\
\hline 40 & 0.054867 & 0.004119 & 0.118867 & 0.004907 & 0.231533 & 0.003067 \\
\hline 50 & 0.077333 & 0.003839 & 0.143667 & 0.004380 & 0.284333 & 0.002373 \\
\hline 60 & 0.072800 & 0.000817 & 0.153467 & 0.005664 & 0.306467 & 0.003345 \\
\hline
\end{tabular}

Table 1: Esterase activity of mCES2 (mouse Carboxyl ESterase 2) and NTC (Non-Template Control) samples using pNPA method. Data table of Fig $2 \mathrm{~d}$ representing time dependent and dose-dependent curve shown above as absorbance at $410 \mathrm{~nm}$. 


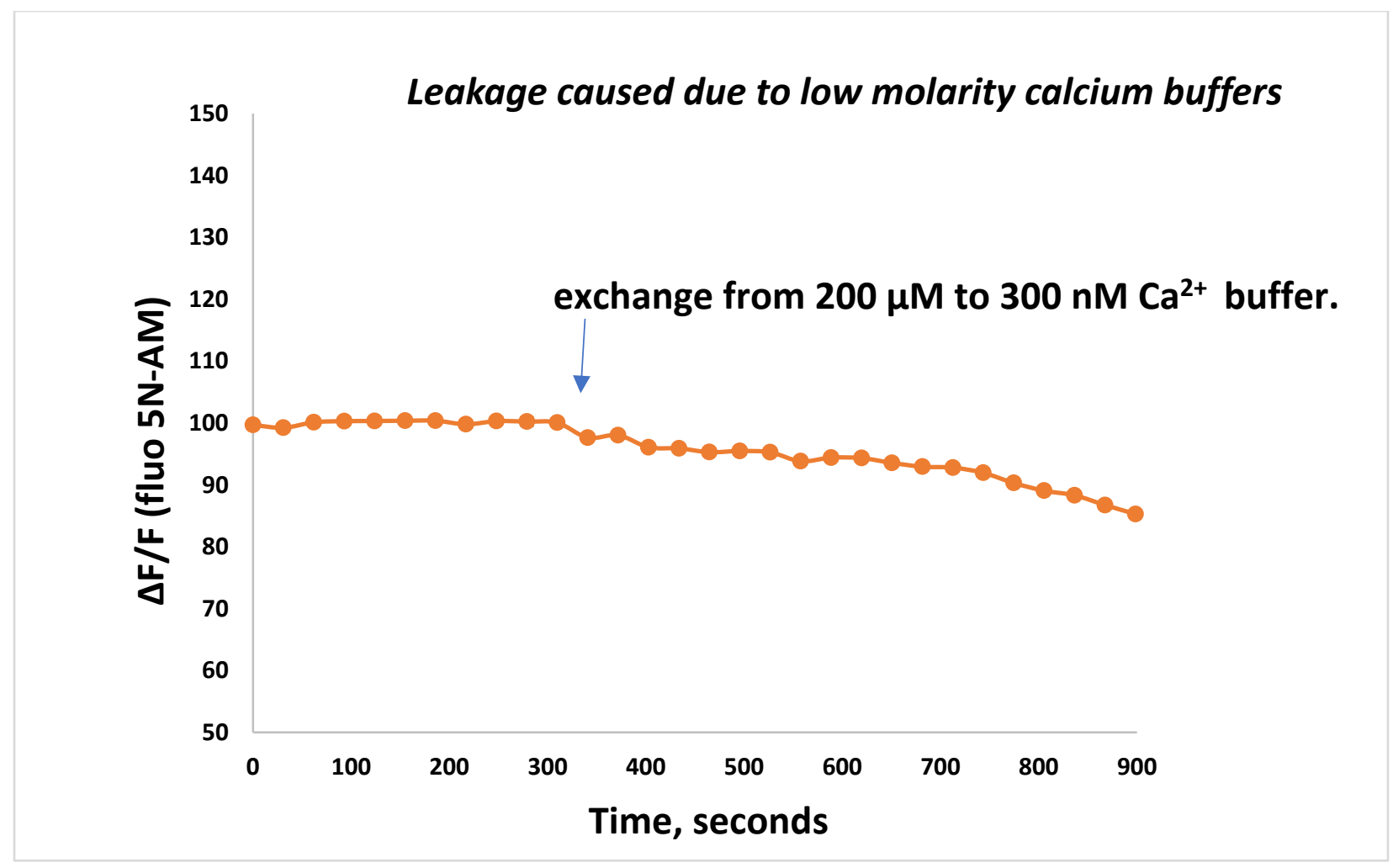

Supplementary data 2: Gradual leakage caused due to change in the buffer from $200 \mu \mathrm{M}$ to $300 \mathrm{nM}$. 